\title{
38. THE EVOLUTION OF THE MAZAGAN CONTINENTAL MARGIN: A SYNTHESIS OF GEOPHYSICAL AND GEOLOGICAL DATA WITH RESULTS OF DRILLING DURING DEEP SEA DRILLING PROJECT LEG 791
}

\author{
E. L. Winterer, Scripps Institution of Oceanography \\ and \\ K. Hinz, Bundesanstalt für Geowissenschaften und Rohstoffe, Hannover
}

\begin{abstract}
Combining the results of drilling during Leg 79 with other on- and offshore regional geological and geophysical data, we infer the following history for the evolution of the Mazagan sector of the Northwest African margin:

1. Rifting began in the Triassic, by crustal thinning associated with listric faulting, creating a series of basins and intervening highs. The basins received continental clastic sediments from erosion of the granitic highs. By the close of Triassic time, halite with minor potash was being deposited in shallow marine salt pans across a rift-valley system, perhaps a little below global sea level, stretching from the base of the Mazagan margin (Site 546), to the base of the Nova Scotia margin, some $150-200 \mathrm{~km}$ northwestward.

2. Marine waters quickly drowned the basin to a depth of few hundred meters during the Early Jurassic, by some combination of subsidence (perhaps with faulting) or basin flooding, and the shoreline advanced eastward, probably to a position not far west of Site 545. During the later part of the Early Jurassic and during Middle Jurassic time, shallowwater carbonate banks occupied parts of the fault block near Site 544 and supplied debris downslope to the area of Site 547, where hemipelagic radiolarian marls were being deposited in a slowly subsiding basin a few hundred meters deep, intermittently poorly ventilated.

3. At about the end of the Bathonian, as the earliest seafloor spreading began in the central Atlantic, faulting and slightly accelerated subsidence-perhaps accompanying renewed crustal stretching - recommenced, this time especially affecting the more proximal parts of the margin near Site 545, creating the main structural relief of the Mazagan Escarpment. This faulting probably reached its maximum in Late Jurassic time, and was accompanied or immediately followed by a great transgression-the Atlantic transgression. Oxfordian carbonate reefs established themselves along the edge of the Mazagan Plateau and contributed reef talus to the slopes below. An isolated reef perched atop the fault block at Site 544 and shallow-water debris tumbled down the slopes to Site 547.

4. Subsidence continued during Early Cretaceous times, but no sediments of this age were deposited (permanently) on the Mazagan Slope, perhaps because most terrigenous supplies were blocked by a submarine swell over an old granitic fault block about $15 \mathrm{~km}$ southeast of the Plateau edge. Huge quantities of terrigenous sand were delivered to the offshore Moroccan Basin by turbidity currents flowing down the continental slopes south of Mazagan.

5. In Aptian time hemipelagic sediments (clayey nannofossil ooze) began depositing rapidly on the Mazagan Slope and accumulation continued through the Albian and most of the Cenomanian. The Slope sediments often slumped or were transported farther downslope in debris flows. Site 544, now a deep bank, stood clear of sediments.

6. After a period of erosion and/or nondeposition in Turonian-Santonian time, debris flows were active again on the Slope during Campanian and Maestrichtian and, intermittently, during Paleocene and Eocene times. Erosion at the top of the Slope cut progressively deeper into older sediments.

7. A thin and incomplete record of Oligocene chalks was truncated by a major unconformity, and then sedimentation of hemipelagic clayey nannofossil ooze resumed on the Slope in the Miocene. All Leg 79 Sites record a hiatus that eliminates sediments of the Tortonian Stage of the Upper Miocene, perhaps because of vigorous thermohaline currents across the Slope at that time.
\end{abstract}

\section{INTRODUCTION}

Previous geological and geophysical investigations of Northwest Africa indicated that scientific drilling on the Mazagan sector of the continental margin off central Morocco offered a unique opportunity to study (i) the subsidence history of a passive continental margin bordering the proto-Atlantic, (ii) the tectonic processes that affected the evolution of the margin, and (iii) the stratigraphy, evolution, and depositional environment of carbonate platforms, typical of the tropical and subtropical belts of the Mesozoic Atlantic Ocean.

\footnotetext{
${ }^{1}$ Hinz, K., Winterer, E. L., et al., Init. Repts. DSDP, 79: Washington (U.S. Govt. Printing Office).

2 Addresses: (Winterer) Scripps Institution of Oceanography, La Jolla, CA 92093; (Hinz) Bundesanstalt für Geowissenschaften und Rohstoffe, D-3000 Hannover 51, Federal Republic of Germany.
}

Glomar Challenger drilling on the Mazagan sector was officially proposed in 1980, and was accepted by the JOIDES Planning Committee late in 1980. Leg 79 actually began on April 15, 1981, when Glomar Challenger steamed out of Las Palmas toward the Mazagan Plateau, and ended in Brest on May 30, 45 days later. Thirty-four days were spent at 4 drill sites, 2 days in dry dock in Lisbon, and 9 days in transit.

In the following chapter, we first describe the regional physiographic and geologic setting of the Mazagan sector and then describe and interpret the reflection seismic data collected before Leg 79 began, in terms of the structural geology and stratigraphic history. We then summarize the main factual results of the drilling program as a prelude to the construction of a model for the evolution of the Mazagan sector from the Triassicto the Recent, emphasizing crustal stretching by faulting, multiphase subsidence, and the sequential development of 
sedimentary facies that record not only an evolution of environments from alluvial through shallow-water marine carbonate to hemipelagic and pelagic, but also the progressive development of the Mazagan Plateau, Escarpment, Slope, and deep-sea basin that we see today. We also attempt to relate the evolution inferred for this one transect across a margin to the broader question of the early opening history of the Central Atlantic.

\section{REGIONAL PHYSIOGRAPHY AND GEOLOGIC SETTING}

The area of DSDP Leg 79 is part of the Moroccan continental margin, which has a varied physiography (Fig. 1, back pocket), (McMaster and LaChance, 1968; Summerhayes et al., 1971; Robb, 1971; Tooms et al., 1971; Jacobi et al., 1975; Uchupi et al., 1976). The shelf width averages about $40 \mathrm{~km}$, but varies from $13 \mathrm{~km}$ at Cap Rhir to $80 \mathrm{~km}$ south of latitude $29^{\circ} \mathrm{N}$. The shelf break generally occurs at the $150 \mathrm{~m}$ depth contour. The continental slope and rise extend from the shelf break to 1500 $m$ depth in the south, east of Fuerteventura, and to about $4000 \mathrm{~m}$ in the north, north of Cap Cantin.

The continental margin of Morocco consists of several distinctive segments characterized by their morphology, seismic sequences, and structural elements (Hinz, Dostmann, et al., 1982). On the inner continental margin, the contrasting provinces include, from south to north:

1. The North Tarfaya sector, bounded to the north by the Agadir Canyon system;

2. The Tafelney Plateau, a large marginal plateau along the seaward extension of the Western High Atlas;

3. The Essaouira segment, distinguished by an irregular slope morphology;

4. The Mazagan continental margin segment off the Moroccan Meseta, characterized by the Mazagan Plateau;

5. The pre-Rif segment, which forms a seaward extension of the onshore Rharb Basin.

Seaward of the continental slope and rise the conspicuous morphological provinces are:

1. The East Canary Ridge, which runs northeast from the eastern Canary Islands to Conception Bank.

2. A broad submarine ridge that includes the Salvage Islands and that lies adjacent to the East Canary Ridge on the west. The ridge is characterized by several seamounts and is separated from the Madeira-Tore Rise by an abyssal plain.

Turning now from physiography to geology, we can subdivide the onshore Atlantic coastal region of Morocco (Choubert and Marcais, 1952; Ambroggi, 1963; FaureMuret and Choubert, 1971; Robb, 1971), from north to south, into the following geologic units (Fig. 2, back pocket):

1. The Rif, an Alpine-type orogene distinguished by numerous overthrusts;

2. The Rharb Basin, a Molasse-like trough between the Rif and the Moroccan Meseta;

3. The Doukkala Basin, in which Mesozoic-Tertiary sediments as much as $1000 \mathrm{~m}$ thick overlie the Moroccan Coastal Meseta Platform;
4. The Southwestern Moroccan Basin, bounded to the north by the Moroccan Coastal Meseta, to the east by the Variscan-Paleozoic complex of the High Atlas, and to the south by the Anti-Atlas. Three sub-basins are grouped under the name Southwestern Moroccan Basin: the North Atlas Basin, also called the Essaouira Basin or Mogador Syncline, which is characterized by salt diapirs; the Haha Basin, also known as the Western High Atlas or the High Central Zone, which is an uplifted block where Lower Cretaceous and Jurassic sediments are exposed; and the South Atlas Basin, also called Agadir Basin, which, together with the Tertiary Souss Trough adjacent to the south, forms a sub-basin of the North Atlas Basin;

5. The stable Anti-Atlas Platform, a Precambrian high with interposed Variscan metamorphic rocks belonging to the West African craton.

The geology of the continental margin of Morocco has been treated by many authors (Robb, 1971; Summerhayes et al., 1971; Luyendyk and Bunce, 1973; Uchupi and Emery, 1974; Hayes and Rabinowitz, 1975; Renz et al., 1975; Seibold and Hinz, 1974, 1976; Watkins and Hoppe, 1979; Wissmann and von Rad, 1979; Vail et al., 1980; Lancelot and Winterer, 1980; Roeser, 1982; Weigel et al., 1982; Jansa and Wiedmann, 1982; Hinz, Dostmann, et al., 1982; Hinz, Winterer, et al., 1982).

A dominant structural unit of the continental margin of Morocco is the north-northeast-trending zone of piercement structures (Beck and Lehner, 1974; Uchupi and Emery, 1974; Uchupi et al., 1976; Hinz and Seibold, 1980; Lancelot and Winterer, 1980; Hinz, Dostmann, et al., 1982), including salt diapirs and complex seismic structures, not all of which are necessarily salt diapirs (Hinz et al., 1982). This zone can be mapped from just east of Fuerteventura/Canary Islands northward to at least latitude $34^{\circ} 30 \mathrm{~N}$ over a distance of $800 \mathrm{~km}$. Before drilling during Leg 79, it was thought that nearly all the piercement structures represented salt domes. The salt is generally assumed to be mainly of Late Triassic age (Salvan, 1974; Van Houten, 1977; Brown, 1980). The western boundary of the piercement zone is irregular but sharply defined. Irregularities in this boundary may represent initial-rift offsets, thus indicating ancient fracture zones. The piercement zone is $40-50 \mathrm{~km}$ wide in the south and widens northward. In the south the piercement zone lies $10 \mathrm{~km}$ to $45 \mathrm{~km}$ seaward of the Upper Jurassic carbonate platform; farther to the north it becomes wider and extends into the southwestern Moroccan coastal basin, where it overlies Paleozoic basement. In the deep offshore, the salt is thought to overlie thin continental crust contaminated by oceanic crustal materials (Hinz, Dostmann, et al., 1982).

The eastern boundary of the Nova Scotia evaporite belt (Jansa and Wade, 1975; Jansa et al., 1980) correlates well with the western boundary of the Moroccan piercement zone. It thus seems likely that before the separation of the African and North American plates a common evaporite basin existed. The present-day seaward boundaries of the two evaporite provinces probably lie near an isochron and may mark the boundary between continental and oceanic crust (Hinz, Dostmann, et al., 1982; Roeser, 1982). 
A prominent magnetic anomaly nearly coincides with the western edge of the Moroccan piercement zone, as shown in Figure 2 and Figure 3, back pocket. The magnetic anomaly, called S-1 by Roeser (1982), is most probably a feature conjugate to that portion of the East Coast Magnetic Anomaly (ECMA) lying north of the New England Seamount chain, and is interpreted to represent the initial rifting zone (Roeser, 1982). Seaward of magnetic lineation S-1 is the Jurassic "Quiet Zone," approximately $400 \mathrm{~km}$ wide. If this zone is underlain entirely by oceanic crust and if spreading rates were around 1.2 $\mathrm{cm} / \mathrm{yr}$., as proposed by Vogt and Einwich (1979), then seafloor spreading would have commenced late in the Early Jurassic. But if seafloor spreading actually began in the Early Jurassic it is not obvious why seafloor spreading anomalies are not recorded, unless polarity reversal frequency was too fast to be resolvable by surface measurements of the magnetic field (Ogg and Steiner, in press). Another possible explanation (Gradstein and Sheridan, 1983) is that the seafloor spreading began much later, at about the end of Bathonian time, and that the initial drifting occurred at a faster spreading rate entirely within a time of constant or rapidly alternating polarity. The results of drilling at Site 534 in the Western Atlantic during DSDP Leg 76 support this hypothesis in documenting a mid-Callovian date for magnetic anomaly M-28 (Sheridan, Gradstein, et al., 1983). This implies much faster spreading rates during the Graham (Jurassic) magnetic interval and suggests that in the area seaward of the Mazagan sector seafloor spreading may also have started late in the Bathonian seaward of the area of DSDP Leg 79. We believed this hypothesis might be tested by drilling during Leg 79 .

\section{SEISMIC DATA BASE}

The locations of the existing multichannel seismic reflection profiles from the area of Leg 79 seaward of the Mazagan Plateau off Central Morocco, of single-channel seismic lines of Vema cruise No. 3013 and Meteor cruise No. 46, and the underway geophysical measurements from Glomar Challenger from this area are shown in a reduced scale in Figure 4. A location map of the seismic lines on a larger scale is given in Figure 5 (back pocket).

The multichannel seismic profiles were measured by the Bundesanstalt für Geowissenschaften und Rohstoffe (BGR) during Meteor cruises No. 39 (1975) and No. 53 (1980), and during the Valdivia West Africa cruise (1979). These seismic data were processed by BGR. The technical specifications for the different multichannel seismic profiles are listed in Table 1.

The 24-fold seismic profiles are shown in Figures 6 and 7 (back pocket). Figure 6 and the lower two panels of Figure 7 present Meteor lines $M$ 53-03/-07/-08/-06/-09 and Valdivia lines $V A 79-02 /-03$, running approximately northwest-southeast from the Mazagan Plateau across the steep Mazagan Escarpment to the deep sea. Lines $M$ $53-02 /-10$ and $V A$ 79-05/-04, trending approximately parallel to the steep continental slope, are presented in Figure 7.
In order that the reader may be free to interpret the seismic records, none of the seismic markers and/or boundaries of seismic sequences has been labeled in backpocket Figures 6 and 7. A discussion of the correlation between drill results and seismic reflection horizons is included in the site chapters, this volume.

Common and characteristic seismic features in both single-channel and multichannel seismic records from the area of DSDP Leg 79 are:

1. Diffractions with distinctive curvature;

2. Multiple diffractions that interfere with each other. The diffractions most probably are from strata ending at a fault and/or steep flank of diapirlike structures;

3. Steeply inclined events having a moderately high frequency with several cycles (see upper and middle part of Figure 8, back pocket, SP 2030-2080, 1650-1750, $1360-1440,1170-1220,450-500)$. The inclined events are commonly superimposed on diffractions, and could be either primary reflections or refractions in higher-velocity rocks reflected at faults or steep lithologic boundaries.

With the existing seismic data it is not possible unequivocally to distinguish primary reflections from diffractions and reflected refraction events in the area of DSDP Leg 79.

Although migration considerably improves the quality of the stacked seismic data (see Figure 8, middle part), we are still faced with the problem of whether the widespread steeply dipping events are primary reflections, multiple diffractions, reflected refractions, or side echoes. The internal seismic pattern and the seismic pattern of the flanks of the salt diapir drilled at Site 546 and of the sialic block drilled at Site 544 are very similar (Figure 9), demonstrating that it is difficult clearly to distinguish salt structures from faulted and tilted continental basement blocks solely on the basis of seismic data. Unfortunately, studies of gravity anomalies do not help solve the problem. In this region, the great depth of the structures relative to their geographic extent produces gravity anomalies differing from one another by only a few mgals, differences which are small compared with the large anomalies of more than 100 mgals caused by the strong density contrasts at the seafloor, the top of crystalline basement, and the Mohoroviciić discontinuity.

\section{INTERPRETATION OF THE SEISMIC DATA FROM THE MAZAGAN CONTINENTAL MARGIN: STRUCTURAL ELEMENTS, SEISMIC SEQUENCES, AND GEOLOGICAL IMPLICATIONS}

Although we recognize that, given the existing coarse grid of multichannel seismic lines and the difficulties in interpretation already discussed, the true nature of various structures in the area of DSDP Leg 79 remains obscure, our best guess on their nature and on the fault pattern is shown in the structural map (Fig. 10, back pocket; see also lower part of Fig. 8, back pocket).

The dominant topographic feature of the Mazagan continental margin segment is the steep Mazagan Escarpment that forms the seaward edge of the Mazagan Plateau, which lies seaward of the Moroccan Meseta in $\mathbf{5 0 0}$ 


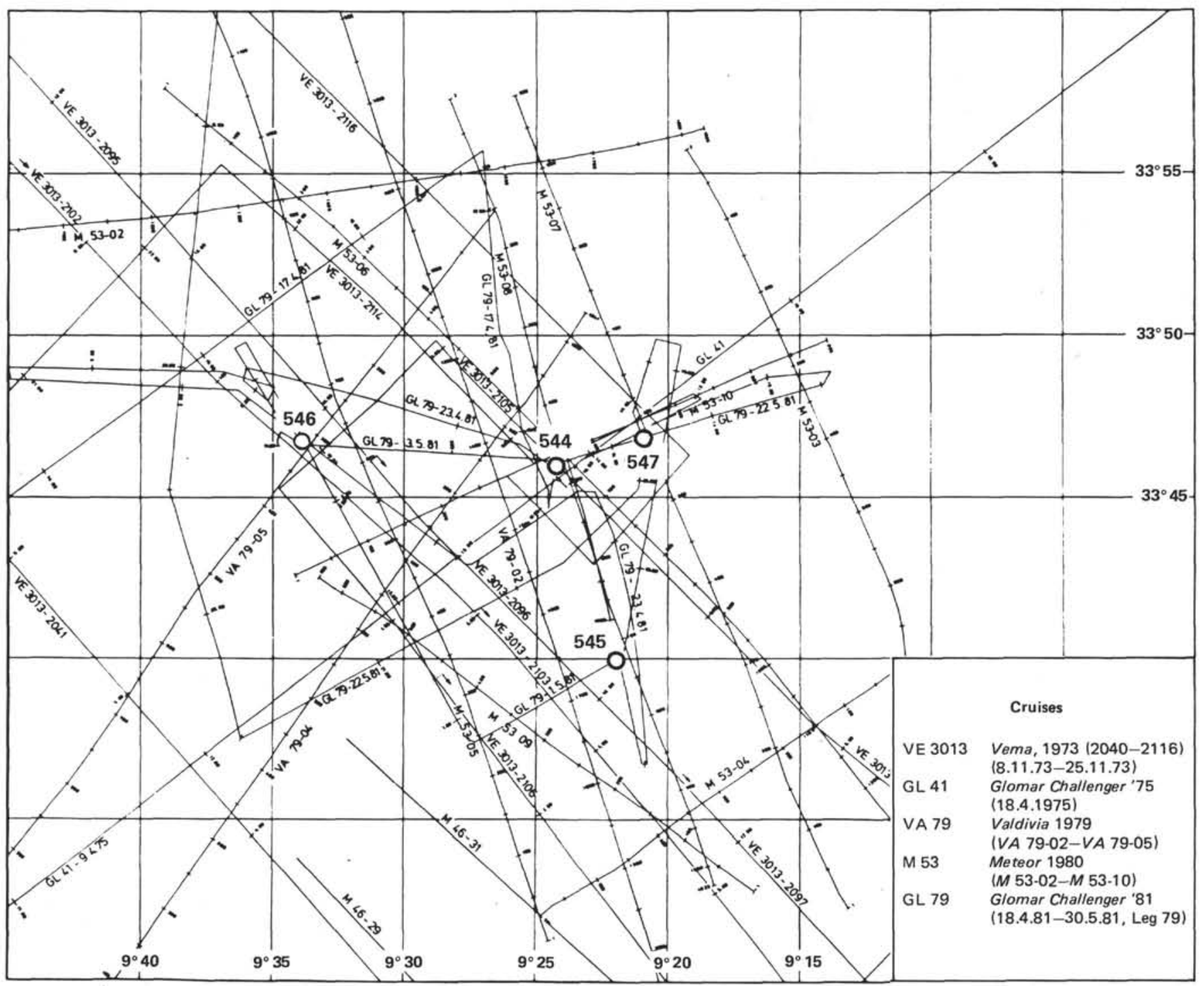

Figure 4. Location of seismic reflection lines in the Mazagan sector of the Moroccan continental margin. See Figure 5 (back pocket) for a largerscale, more detailed version.

to $1600 \mathrm{~m}$ water depth. The results of the CYAMAZ deep submersible dives (Auzende et al., this volume) show that the Mazagan Escarpment consists of a staircase of step-fault blocks with steps ranging from 10 to $200 \mathrm{~m}$ in height. On the outer Mazagan Plateau near the Mazagan Escarpment, Seismic Sequence Ma 3, which is approximately 0.3 to $0.5 \mathrm{~s}$ (TWT) thick (i.e., about 600 to $1100 \mathrm{~m}$, assuming an internal velocity of $4500 \mathrm{~m} / \mathrm{s}$ ), and which is characterized by an internal reflection pattern consisting of subparallel reflectors, overlies what we infer to be synrift sediments of presumably Triassic and possibly even Early Jurassic age. The thickness of the synrift sediments is difficult to define in the existing seismic records, but may exceed $1000 \mathrm{~m}$ in the center of what we interpret as half-grabens beneath Sequence Ma 3 on the Mazagan Plateau.

Southeast of the Mazagan Plateau, in the Doukkala Basin, as much as $3000 \mathrm{~m}$ of terrestrial and evaporite sediments fill Hercynian synclinal structures and Triassic fault troughs (Wissmann and von Rad, 1979). Brown
(1980) reported on Upper Triassic rocks in the Argana Valley of southern Morocco consisting of 2,500 to 5,000 m of red brown clastic deposits.

On the Mazagan Plateau, the ages of the unconformities B* and B (see right side of Fig. 8) that form the boundaries of Sequence Ma 3 are unknown. According to the CYAMAZ results (Auzende et al., this volume), Sequence Ma 3 probably consists of shallow-water carbonate-platform sediments. We interpret Reflector B* as representing the beginning of the buildup of a widespread, uniform, carbonate platform within the Mazagan sector of the continental margin near the end of Middle Jurassic time, an episode which was contemporaneous with the start of seafloor spreading in the central North Atlantic. We interpret Reflector B as the top of the shallow-water platform limestones. Although the exact stratigraphic age of unconformity B, which caps Seismic Sequence Ma 3 on the Mazagan Plateau, is still unknown, a Tithonian age seems reasonable: in the area of Jadida Canyon and at a depth of about $2000 \mathrm{~m}$ along 
Table 1. Technical specifications for seismic reflection profiles obtained during cruises by research vessels of the Bundesanstalt für Geowissenschaften und Rohstoffe in the Mazagan region.

\begin{tabular}{|c|c|c|c|}
\hline & Meteor 39 & Valdivia VA 79 & Meteor 53 \\
\hline Sound source & $\begin{array}{l}\text { Two } 300 \text { in }^{3} \text { air guns, } \\
2000 \text { psi operating pressure }\end{array}$ & $\begin{array}{l}\text { Three } 300 \text { in }^{3} \text { air guns, } \\
2000 \text { psi operating pressure }\end{array}$ & $\begin{array}{l}\text { Three } 300 \text { in }^{3} \text { air guns, } \\
2000 \text { psi operating pressure }\end{array}$ \\
\hline Streamer & $\begin{array}{l}\text { AMG } 37-43 \text { Geomecanique, } \\
12 \text { traces, length } 1500 \mathrm{~m}\end{array}$ & $\begin{array}{l}\text { AMG } 37-43 \text { Geomecanique, } \\
24 \text { traces, length } 2606 \mathrm{~m} \text {, } \\
\text { depth } 15 \mathrm{~m}\end{array}$ & $\begin{array}{l}\text { AMG } 37-43 \text { Geomecanique, } \\
24 \text { traces, length } 2500 \mathrm{~m} \text {, } \\
\text { depth } 45 \mathrm{~m}\end{array}$ \\
\hline $\begin{array}{r}\text { Shotpoint } \\
\text { spacing }\end{array}$ & $50 \mathrm{~m}$ & $50 \mathrm{~m}$ & $50 \mathrm{~m}$ \\
\hline Recording & $\begin{array}{l}\text { Raytheon MDS-8, } \\
\text { 24-channel }\end{array}$ & DFS-V, 24-channel & DFS-V, 24 channel \\
\hline \multirow[t]{2}{*}{ Processing } & $\begin{array}{l}\text { Raytheon RDS- } 500 \text { comp.; } \\
\text { Input tape format } \\
\text { SEG-B, } 800 \text { bpi, } \\
\text { sampling rate } 4 \text { ms. }\end{array}$ & $\begin{array}{l}\text { Raytheon RDS- } 500 \text { and } \\
\text { RDS-704 computers; } \\
\text { Input tape format } \\
\text { SEG-B, } 800 \text { bpi, } \\
\text { sampling rate } 4 \mathrm{~ms} \text {. }\end{array}$ & $\begin{array}{l}\text { Raytheon RDS- } 500 \text { and } \\
\text { RDS- } 704 \text { computers; } \\
\text { Input tape format } \\
\text { SEG-B, } 800 \text { bpi, } \\
\text { sampling rate } 4 \text { ms. }\end{array}$ \\
\hline & $\begin{array}{l}\text { Steps: } \\
\text { (1) Uniprep } \\
\text { (2) Suprsort } \\
\text { (3) Amplitude correct. } \\
\text { (4) Velocity analysis } \\
\text { (5) Horizontal stacking, } \\
\text { 12-fold } \\
\text { (6) Frequency filter: } \\
\text { low cut } 8-15 \mathrm{~Hz} \text {, } \\
\text { high cut } 55-65 \mathrm{~Hz} \\
\text { (7) Display }\end{array}$ & $\begin{array}{l}\text { Steps: } \\
\text { (1) Uniprep } \\
\text { (2) Suprsort } \\
\text { (3) Amplitude corrections } \\
\text { (4) Velocity analysis } \\
\text { (5) Horizontal stacking, } \\
24 \text {-fold } \\
\text { (6) Frequency filter: } \\
\text { low cut } 10-15 \mathrm{~Hz} \text {, } \\
\text { high cut } 45-55 \mathrm{~Hz} \\
\text { (7) FK-Migration } \\
\text { (8) Display }\end{array}$ & $\begin{array}{l}\text { Steps: } \\
\text { (1) Uniprep } \\
\text { (2) Suprsort } \\
\text { (3) Amplitude corrections } \\
\text { (4) Velocity analysis } \\
\text { (5) Horizontal stacking, } \\
\text { 24-fold } \\
\text { (6) Frequency filter: } \\
\text { low cut } 10-15 \mathrm{~Hz} \text {, } \\
\text { high cut } 45-55 \mathrm{~Hz} \\
\text { (7) FK-Migration } \\
\text { (8) Display }\end{array}$ \\
\hline $\begin{array}{l}\text { Integrated satellite } \\
\text { navigation system type }\end{array}$ & INDAS & INDAS II-E & INDAS \\
\hline
\end{tabular}

the central Mazagan Escarpment the CYAMAZ dives (Auzende et al. this volume) sampled a sequence, several hundred meters thick, consisting of well-bedded Berriasian to Barremian sandy bioclastic limestones deposited in a slope environment and Lower Cretaceous sandy bioclastic limestones and oolitic ironstones that overlie the platform carbonates.

From the CYAMAZ data, Seismic Sequence Ma 2.2 on the Mazagan Plateau (Fig. 8) is interpreted to consist of similar lower to middle Lower Cretaceous rocks. A distinct unconformity, probably of mid-Cretaceous age, separates Sequence Ma 2.2 from the overlying Seismic Sequence Ma 2.3. The latter is characterized by a noncoherent internal reflection pattern, and most plausibly consists of the Upper Cretaceous to Paleogene breccias and Paleocene calcisiltites observed on the CYAMAZ dive 92. The top of Sequence Ma 2.3 is defined by a clear unconformity (Reflector R), possibly formed during a global(?) regression in the Paleocene and/or Eocene.

The variety of rocks of Early Cretaceous to Paleogene age sampled during the CYAMAZ dives, and presumably comprising the Seismic Sequences Ma 2.2 and Ma 2.3, suggests that the rates of subsidence and sedimentation on the Mazagan Plateau were not uniform either in time or space. The distinct change in thickness of Sequences $\mathrm{Ma} 3$ and $\mathrm{Ma} 2.2$ at the northwestern edge of the elongate fault block (e.g., SP 2080-2370, Fig. 8) that crosses the Mazagan Plateau in a northeast direction (Fig. 10) suggests that gradual, slow subsidence had already started by the Late Jurassic on the Mazagan Plateau, accompanied by faulting and apparently followed by increased rates of subsidence or sediment accumulation in the Early Cretaceous. The displacement of Reflector B at the fault (SP 2080, Fig. 8) is about $0.5 \mathrm{~s}$ (TWT), which is relatively small compared with the large offsets at some faults (e.g., SP 1200-1250, 1400-1450, $1550-1600$, Fig. 8) seaward of the Mazagan Plateau.

The steep transition from the Mazagan Plateau down the narrow Mazagan Escarpment and Slope to the deep sea is associated with a series of faults. The adjacent strip of deep-sea basin, $75 \mathrm{~km}$ to $100 \mathrm{~km}$ wide, contains tilted fault blocks and diapiric structures whereas farther seaward, beyond Magnetic Anomaly S-1, these are absent. In the westernmost part of the basin, Sequence Ma 3, which is about $0.2 \mathrm{~s}$ (TWT) thick and which we interpret as consisting of Jurassic deep-water carbonates, shows little relief and is disrupted only locally by piercing salt (SP 150-200, 380-420, Fig. 8). The thickness of the underlying salt-bearing synrift sediments is difficult to define.

In contrast, adjacent to the Mazagan Plateau, in the area of DSDP Leg 79, the Jurassic carbonate sequence Ma 3 is much tilted and broken by faults. Taken together with the data on thickness and facies of the Jurassic carbonates drilled at Sites 544, 545, and 547, the seismic data suggest that (i) during the early part of the Late Jurassic the area of DSDP Leg 79 formed the somewhat decoupled distal part of the Mazagan Plateau, and (ii) the subsidence was accompanied by listric faulting, resulting in the development of rotated blocks with intervening deeper half-graben basins about $3 \mathrm{~km}$ to $10 \mathrm{~km}$ wide (Fig. 8, SP 1000-1700). The individual blocks are 

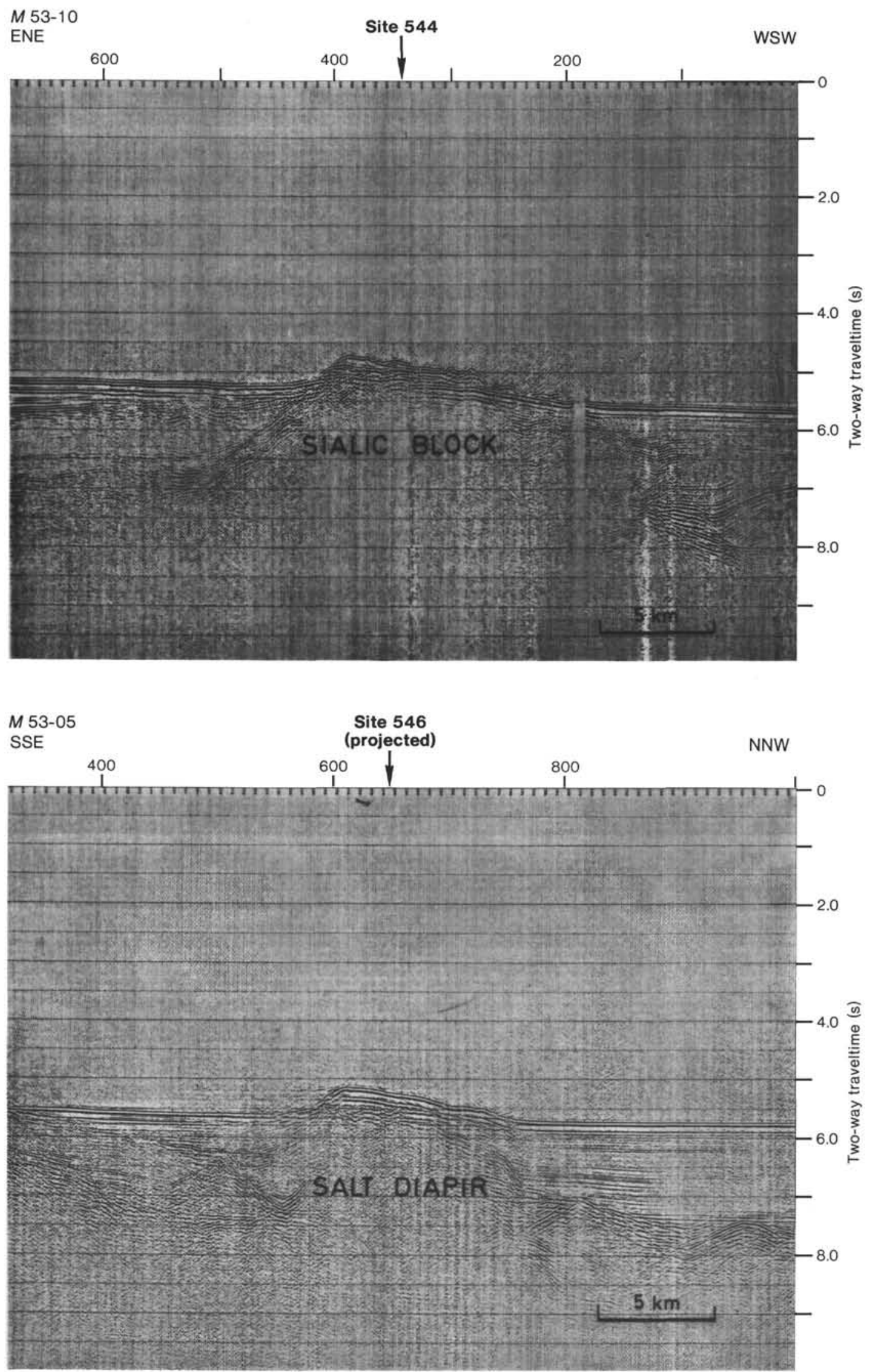

Figure 9. Seismic records across the sialic block drilled at Site 544 (upper part) and across the salt structure drilled at Site 546 (lower part). 
characterized by pronounced, upturned, angular edges and steep, narrow fault zones on their seaward flanks.

The vertical separation on individual listric faults is difficult to estimate accurately, but they are in the range of a few hundred to $3000 \mathrm{~m}$. The predominant trend of the faults and the rotational blocks they outline is northeast. East-trending faults are less common. En echelon faults are clearly recognizable within the broad transition zone from the northern Mazagan Plateau to the deep sea. A pronounced north-trending fault zone appears to intersect the northeast-striking faults between Sites 544 and 545 and continues into the steep and fault-controlled Mazagan Escarpment south of latitude $33^{\circ} 35 \mathrm{~N}$.

The tilted fault blocks clearly indicate crustal extension, but the amount of the extension cannot be accurately estimated here because we still do not know the detailed fault geometry, which is partly masked and modified by salt movements. The Late Jurassic phase of rapid subsidence associated with renewed rotational block faulting may have initiated salt movements. With only few exceptions, primary and secondary rim synclines are lacking around salt structures in the area of DSDP Leg 79. This suggests that the salt dome drilled at Site 546 and the salt structures interpreted from seismic data are not pure, vertical, buoyant, salt structures but tectonically controlled intrusions. The salt structures lie in a band seaward of the Mazagan Slope, which formed the distal edge of the stable Mazagan Plateau during Late Triassic and Early Jurassic time. We suggest that the alignment of the salt structures roughly mirrors the structural pattern of the synrift stage. This hypothesis implies that before the separation of the African and North American plates, a rift basin existed which was already subdivided into a series of differentially subsiding and infilled fault basins with intervening swells. Late Jurassic faulting may have followed some of the older structures.

The rapid subsidence accompanied by rotational block faulting which led to a division of the area of DSDP Leg 79 into very deep depressions and high-standing blocks presumably ceased shortly before deposition of Seismic Sequence Ma 2.3 or even before deposition of Sequence $\mathrm{Ma}$ 2.2. It was in this highly differentiated area that Sequences Ma 2.3 and Ma 2.2 were deposited. The sequences are characterized by subparallel patterns of reflectors with clear lap onto the sloping surfaces of the Jurassic carbonates and against the intensively faulted seaward flanks of the rotational blocks. The results of Leg 79 show that Seismic Sequence Ma 2.3 consists of lower Upper Aptian to Upper Cenomanian grayish green nannofossil claystone and mudstone. Deposition occurred in bathyal depths but well above the calcite compensation depth and was associated with slumping and sliding. Deposition of Sequence Ma 2.3 was followed by intensive erosion during post-Cenomanian to Eocene time. By Eocene time, as shown by the isochron map of Reflector R (Tertiary/Cretaceous (Cenomanian) boundary, Fig. 11, back pocket), the present shape of the Mazagan continental margin segment had mainly been formed.

In contrast to the events on the Mazagan Slope drilled during Leg 79, the Late Jurassic phase of rapid subsi- dence and intensive rotational block-faulting did not much affect either the Mazagan Plateau or the westernmost part of the deep-sea diapiric basin. This suggests that subsidence and faulting were time-transgressive across this segment of the continental margin, that is, they began in Late Triassic to earliest Jurassic time in the riftbasin system to the west and later encroached on areas marginal to the rifted basin. The drilling and seismic data suggest two major phases, corresponding to the original creation of a rift basin and to the early stages of seafloor spreading.

After an erosional interval represented by unconformity R, Seismic Sequence Ma 1.1, which consists of clayey nannofossil chalk of Late Cretaceous to late Eocene age, was deposited at Site 547. In the Oligocene, intensive erosion occurred in both the Plateau and deep-sea areas, followed by the deposition of the seismically transparent Sequences Ma 1.2 and Ma 1.3, which at Site 547 consist of lower to middle Miocene nannofossil ooze and upper Miocene to Quaternary foraminiferal-nannofossil ooze.

\section{SUMMARY OF DRILLING RESULTS}

The four sites drilled during Leg 79 constitute a profile-albeit an incomplete profile-across the Mazagan Slope. The most seaward site, Site 546 , is located on a salt dome a few kilometers beyond the foot of the Slope and the most landward site, Site 545 , is located on the upper part of the Slope, below the steep escarpment at the outer edge of the Mazagan Plateau. Site 544 is located on a narrow horst near the foot of the Slope, and Site 547 is located on the landward slope of this fault block.

The profile is incomplete in several important respects. First, only at Site 544 was the entire sedimentary section penetrated through to crystalline basement rocks. Because the salt dome at Site 546 is covered by only a thin cap of Neogene sediments, we have no drill record of the very thick basinal section seaward of the Mazagan Slope. Neither do we have any drill holes on the Mazagan Plateau itself: plans to drill a site there (MAZ-8) had to be abandoned for lack of time during Leg 79 .

Our knowledge of the lithologic succession at the drill sites is good for the Cenozoic and Cretaceous, but in the crucial Jurassic strata the average core recovery rate was only about $40 \%$. What is even more lamentable is the want of any downhole logs: the logging scheduled for Leg 79 had to be cancelled because a dockers' strike in Marseilles prevented delivery of the logging tools to Glomar Challenger in time for the cruise. Without logs, our correlations of lithologic with seismic data are uncertain, especially in the Jurassic.

Another source of uncertainty in the Jurassic strata is the loose biostratigraphic control. Only at Site 547 do we have sufficient control to establish the ages of the rocks to the stage level. At Sites 544 and 545 the Jurassic beds contain only fossils that have age ranges of several stages.

Stratigraphic columns for the four drill sites are shown in Figure 12, which also shows the major unconformities in the sedimentary section. The salient features of 
SITE 546

LAT. $33^{\circ} 46^{\prime} \mathrm{N}$, LONG. $9^{\circ} 33.9^{\prime} \mathrm{W}$

Depth $3992 \mathrm{~m}$

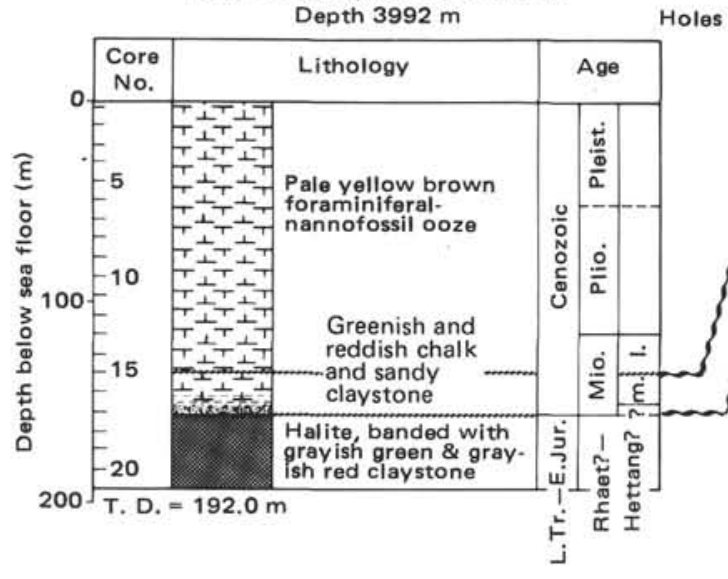

SITE 544

Hole 544: LAT. $33^{\circ} 46.13^{\prime} \mathrm{N}$, LONG. $9^{\circ} 39^{\prime} \mathrm{W}$, Depth $3766 \mathrm{~m}$ Hole 544: LAT. $33^{\circ} 46.13^{\prime} \mathrm{N}$, LONG. $9^{\circ} 39^{\prime} \mathrm{W}$, Depth $3766 \mathrm{~m}$
$544 \mathrm{~A}$ \& 544B: LAT. $33^{\circ} 46.00^{\prime} \mathrm{N}$, LONG. $9^{\circ} 24.26^{\prime} \mathrm{W}$, Depth $3607 \mathrm{~m}$

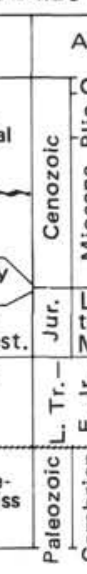

age

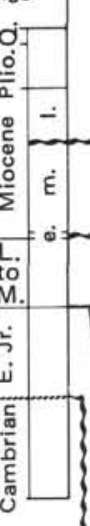

Figure 12. Summary stratigraphic columns for sites drilled during DSDP Leg 79. Correlations between sites are indicated by lines. Wavy lines denote unconformities.

the succession at each site are set out in the paragraphs below:

\section{Site 544}

The crystalline basement at Site 544 is granodioritic gneiss, with plagioclase, $\mathrm{K}$-spar, quartz, biotite and mus- covite grains within a mylonitic epidote-bearing groundmass. According to Kreuzer et al. (this volume), petrographic evidence documents three events: first the intrusion, next the deformation that resulted in mylonitization and partial recrystallization, and last a postdeformative recrystallization in which epidote formed. $\mathrm{K}-\mathrm{Ar}$ dating 
SITE 547

LAT. $33^{\circ} 46.8^{\prime} \mathrm{N}$, LONG. $9^{\circ} 21.0^{\prime} \mathrm{W}$ Depth $3940.5 \mathrm{~m}$

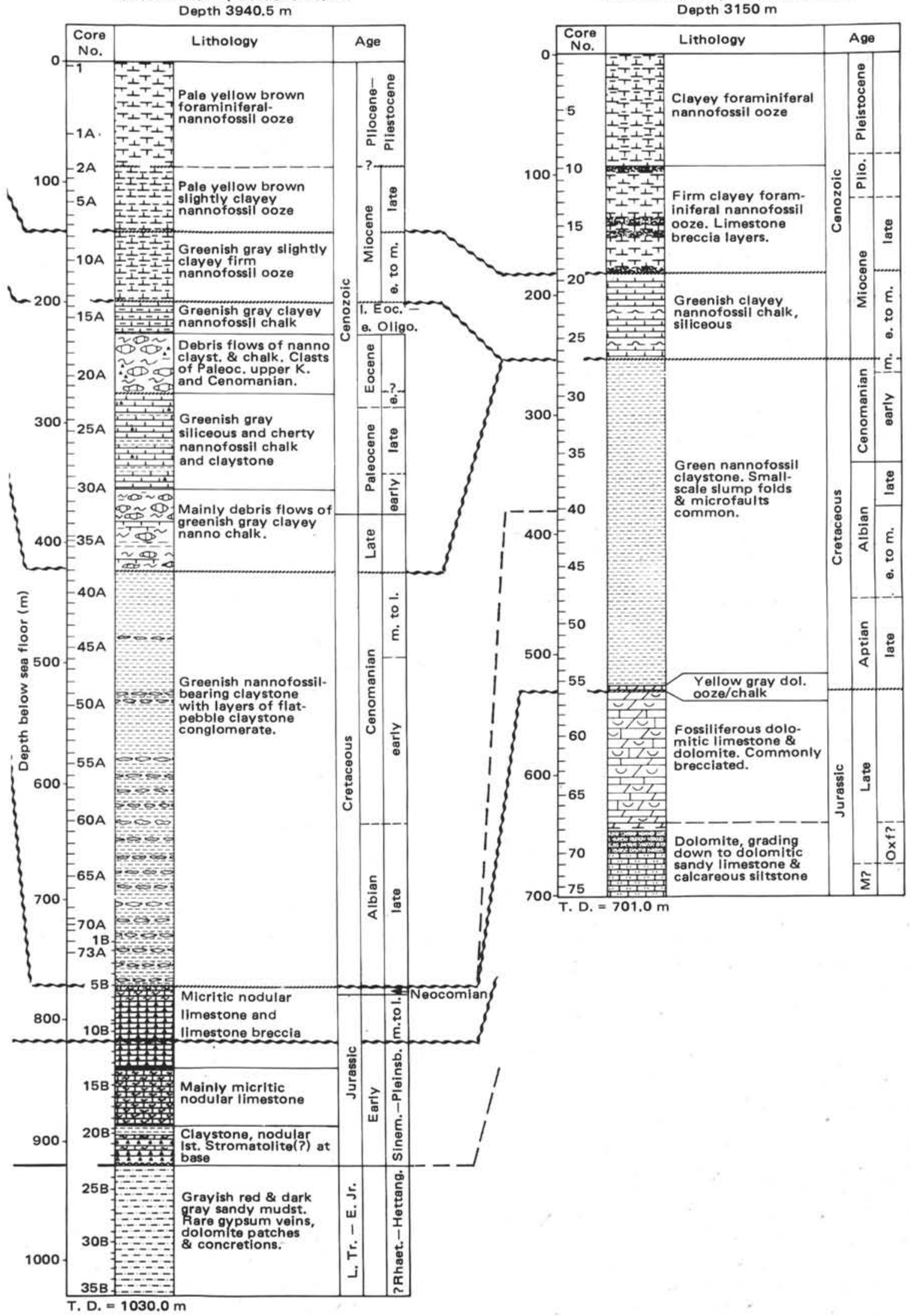

Figure 12. (Continued). 
of predeformation coarse-grained muscovites by Kreuzer et al. gives dates of $519 \pm 21$ and $516 \pm 8 \mathrm{~m}$.y. from which they infer a middle Cambrian age for the cooling age of the granodiorite. $\mathrm{K}-\mathrm{Ar}$ dates on fine-grained muscovite are about 450 m.y. (middle Ordovician), which Kreuzer et al. suggest is the time of mylonitization. These authors speculate that $\mathrm{K}-\mathrm{Ar}$ dates on biotite and K-spar of about 315-370 m.y. point to a Devonian/Carboniferous or Late Carboniferous rejuvenation.

Basement gneiss at Site 544 is overlain by about $45 \mathrm{~m}$ of red beds, consisting mainly of arkosic muddy sandstone and sandy mudstone, pebbly near the base of the section and with mudflow deposits near the top. We interpret this sequence as continental, nonmarine in origin, and probably deposited on the slopes of a hilly, deeply weathered, gneissic terrain in a climate that was at least seasonally humid. No fossils were discovered in the sediments, and the presumed earliest Jurassic or latest Triassic age is based on a lithologic correlation to nonmarine beds at nearby Site 547, from which Fenton (this volume) reports poorly preserved palynomorphs of Late Triassic or Early Jurassic age, lying below marine limestone beds dated as earliest Jurassic.

Very poor core recovery in the upper part of the red bed sequence makes it impossible to determine the nature of the contact with the overlying marine limestone beds. It may be abrupt and represent an unconformity or it may be gradational. We find the former interpretation the more plausible, because the limestone is mainly Middle to Late Jurassic in age, and because no transitional lithologic types were recovered.

Jurassic limestone beds at Site 544 are about $35.5 \mathrm{~m}$ thick and consist mainly of reddish and yellowish brown bioclastic grainstone and wackestone and peloidal cyanobacterial crusts. The formation contains remains of both pelagic and benthic organisms and suggests deposition in moderate (100-200 m) depths (see Steiger and Jansa, this volume), at first in relatively calm and later in more agitated waters. Hardgrounds in the upper part of the unit suggest decreasing sedimentation rates. The age span of the limestone is uncertain: lithologically, it strongly resembles limestone dredged farther south along the upper part of the Mazagan slope, from which Renz et al. (1975) report ammonite remains dated as Oxfordian. In the upper part of the limestones at Site 544 are scarce protoglobigerinoids, which occur most commonly in Oxfordian rocks in Tethys. Fragments possibly of Saccocoma, a pelagic crinoid occurring mainly in Kimmeridgian-age rocks, occur near both the top and base of the formation. Pelagic bivalves, or "filaments," are common nearly throughout the formation, suggesting, by comparison with the common stratigraphic occurrence of "filaments" in Tethyan pelagic limestones, an age from Middle Jurassic to Oxfordian for the limestone at Site 544. The preponderance of the evidence points to an Oxfordian age for most of the formation, but it may range from, say, Callovian to Kimmeridgian.

The abundance of crusts and hardgrounds, the reddish coloration, and the moderate-depth aspect of the benthic faunas suggest slow net rates of accumulation on an outer platform, where pelagic shells could settle.

Cretaceous and Paleogene strata are absent at Site 544, and the Jurassic limestone is overlain abruptly by Neogene hemipelagic sediments about $104 \mathrm{~m}$ thick. Lower Miocene sediments are represented by about $2 \mathrm{~m}$ of greenish glauconitic calcareous claystone and calcareous ooze. Whether this unconformity represents a long (Jurassic-Miocene) period of nondeposition, or whether pre-Miocene sediments were deposited and then eroded is unknown. The position of the site, on the seaward slope of a horst standing well above its surroundings, protects it from sediments derived from the Mazagan Slope (see the geologic cross section in the first panel of Figure 13, later) while exposing it to deep thermohaline boundary currents moving along the base of the Slope. We thus favor the nondeposition alternative.

The lower Miocene sediments are separated from the overlying middle Miocene by a 4-cm layer of greenish calcareous ooze with patches of iron-rich lithified oozean incipient hardground. The hiatus excludes about 5 m.y. of record, close to the middle/lower Miocene boundary. The middle Miocene is about $44 \mathrm{~m}$ thick, and consists of pale yellowish brown clayey foraminiferal-nannofossil ooze. Another hiatus, marked by glauconite and a tendency toward olive gray colors, separates the middle Miocene (Serravalian, N14) from the upper Miocene (Messinian, N17) foraminiferal-nannofossil ooze. The overlying upper Miocene to Pleistocene section of ooze is about $59 \mathrm{~m}$ thick. Reflection profiler records across the drill site (see site chapter, this volume), suggest that several tens of meters of Pleistocene and Recent sediments have been eroded from this site.

Preservation of foraminifers and nannofossils in the Neogene at Site 544, which lies in $3607 \mathrm{~m}$ of water, is good and indicates, in terms of carbonate-dissolution profiles, that the site has been more or less continuously above the lysocline for these fossils during the past 18 m.y.

\section{Site 545}

This site, located on the upper part of the Mazagan Slope a little below the steepest part of the Escarpment at the seaward edge of the Mazagan Plateau, was designed to explore the Jurassic carbonate platform through to crystalline basement, but the bit wore out at a total depth of $701 \mathrm{~m}$, within the platform sequence. With no reentry cone, the site had to be abandoned before all the objectives were reached. Nonetheless, the coring yielded rich dividends, not only on the history and facies relations of the Jurassic rocks, but on the depositional history of mid-Cretaceous slope deposits and on Neogene events that defaced the Mazagan Escarpment.

The drilled section divides itself into three major units, separated by major unconformities: (1) Jurassic limestone, dolomite, and sandy limestone, at least $170 \mathrm{~m}$ thick; (2) mid-Cretaceous greenish claystone, $279 \mathrm{~m}$ thick; and (3) Neogene foraminiferal-nannofossil ooze, with layers of Mesozoic-limestone breccia, about $252 \mathrm{~m}$ thick. The Cretaceous and Cenozoic rocks are much like those 
cored at other sites on Leg 79, but the Jurassic carbonate beds are very different from anything drilled at Sites 544 and 547, only about $10 \mathrm{~km}$ away.

Basement rocks were not reached at Site 545, but seismic reflection data close to the site (see Fig. 22 in site chapter for Site 545, this volume) suggest that the total thickness between the top of the Jurassic carbonate sequence and the top of crystalline basement is not much more than $250 \mathrm{~m}$ (using an interval velocity of $4.5 \mathrm{~km} / \mathrm{s}$ for the Jurassic rocks). Thus, we infer that less than $100 \mathrm{~m}$ of sediment lie below the deepest level reached by the drill. The lithology of the lowest beds (about one-third quartz grains in the lowest core) suggests we were nearing basement.

\section{Jurassic Rocks}

Jurassic strata are about $170 \mathrm{~m}$ thick and consist of intraclast skeletal grainstone, packstone, and wackestone, becoming sandy toward the base. The upper $105 \mathrm{~m}$ is commonly moderately to intensely dolomitized and contains a variety of shallow-water bioclastic materials, and the lower $65 \mathrm{~m}$ is richer in terrigenous debris and contains abundant ammonites and Zoophycos burrows. The shallow-water materials include algae, corals, bryozoans, bivalves, gastropods, serpulids, foraminifers, echinoderm plates, sponge spicules, and tubiphytes. Ooids are common at some levels. The upper $60 \mathrm{~m}$ or so includes brecciated zones, and thin bands of laminated yellow dolomite occur about 76 and $96 \mathrm{~m}$ from the top of the Jurassic sequence. Pelagic and deeper-water fossils-bivalves and sponges-also occur at some levels, along with oolites. The entire sequence can be interpreted (see Steiger and Jansa, this volume) as a progression from subtidal sandy to oolitic sedimentation on a carbonate ramp, followed by mixed shallow-water, nearreef sedimentation, and finally by periplatform talus accumulation.

The age of the carbonate rocks cannot be fixed with precision. A Late Jurassic age is suggested for foraminifers and algae in the upper $70 \mathrm{~m}$ of the unit. An ammonite assigned to the Oxfordian by Renz (this volume) occurred at a level about $108 \mathrm{~m}$ below the top of the carbonate sequence. Nannofossils with an age range of late Pliensbachian to early Bathonian are reported by Wiegand (this volume) from the lowest $36 \mathrm{~m}$ of the sequence, and pollen gains from the lowest $18 \mathrm{~m}$ were dated as Sinemurian-Bajocian by Fenton (this volume). We infer that the lowest beds cored are at least as old as Bajocian. The sandy facies near the base is one we normally associate with fairly rapid accumulation rates, and could plausibly represent only a few millions of years.

The sequence of shallowing, then deepening again, and then the complete cessation of carbonate accumulation suggests that very rapid subsidence/sea-level rise was responsible for drowning the platform. The final periplatform breccias suggest the existence of a healthy carbonate platform nearby upslope to the southeast until the very end.

\section{Cretaceous Rocks}

The Jurassic carbonate rocks are overlain unconformably by a sequence of early late Aptian age (?Schack- oina cabri or Globigerinelloides ferreolensis zones) to middle Cenomanian age (Rotalipora reicheli Zone) totalling about $279 \mathrm{~m}$ thick. The Aptian is about $75 \mathrm{~m}$ thick and contains at its base a meter or so of pale orange dolomitic chalk, which is succeeded by burrowed greenish nannofossil claystone that is cut by numerous microfaults and slump folds. Several zones of fault mélange occur near the base of the unit. The claystone contains a few percent of terrigenous silt and sand and about $0.8 \%$ organic carbon. The overlying Albian is about $110 \mathrm{~m}$ thick and consists mainly of olive green silty nannofossil-bearing claystone, with sponge spicules and radiolarians, and with a few microfolds and faults. A few layers of intraformational clay-pebble conglomerate occur near the top. The Cenomanian is about $94 \mathrm{~m}$ thick and is lithologically like the underlying uper Albian. It also includes layers of clay- and chalk-pebble conglomerate and one of the pebbles contains Nannoconus, an Early Cretaceous nannofossil. Some of the conglomerate layers have sharp, secured bases.

The environment of deposition of the Cretaceous beds was the Mazagan Slope, at bathyal depths, mainly well above the CCD. The abundance of siliceous remains in the Albian and a corresponding decrease in planktonic foraminiferal diversity favoring the simpler morphotypes suggests an expanded oxygen-minimum zone in the early to middle Albian (Leckie, this volume). A few layers of fissile black claystone deposited at the same levels may be the local reflection of more oceanwide black shale occurrences in the mid-Cretaceous.

The average rate of sedimentation for the middle Cretaceous beds was about $16-18 \mathrm{~m} / \mathrm{m}$.y., or about $2.7-3.1$ $\mathrm{g} / \mathrm{cm}^{2}$ per $10^{3} \mathrm{yr}$.

\section{Neogene Sediments}

The upper $252 \mathrm{~m}$ of sediments at Site 545, lying unconformably on the Cenomanian rocks, are Neogene in age. The lowest $71 \mathrm{~m}$, of early and middle Miocene age, consists of burrowed, greenish gray, clayey nannofossil chalk. Carbonate content increases from about $45 \%$ at the base to nearly $80 \%$ at the top, and radiolarians are present throughout, constituting as much as $5 \%$ of the sediment at a few levels in the lower Miocene. Silt-sized terrigenous detritus-mainly quartz-constitutes a few percent of the sediment. This unit had a sedimentation rate of about $10-20 \mathrm{~m} / \mathrm{m}$.y., or $1.3-2.6 \mathrm{~g} / \mathrm{cm}^{2}$ per $10^{3}$ yr.

An unconformity separates the upper Miocene to Recent sediments, about $181 \mathrm{~m}$ thick, from the middle and lower Miocene; it is marked by the base of a layer of limestone breccia about $40 \mathrm{~cm}$ thick. This is the lowest of four similar breccia beds in the upper Miocene, with another in the lower Pliocene. The breccia/conglomerate layers contain subrounded to rounded clasts, some having bivalve borings on their exterior. The clasts represent an extraordinary range of lithologic types, but most are skeletal, oncoidal, and intraclastic packstone, wackestone, and grainstone. Some contain shallow-water corals, echinoderms, sponges, mollusks, etc. Some also contain calpionellids or pelagic bivalves, indicating an open-water site where residemented shallow-water debris accumulated. Most clasts are probably of Upper Juras- 
sic or lowest Cretaceous provenance. One yielded a nannoconid of Berriasian to Barremian age, and another had angular clasts of calpionellid-bearing grainstone reworked in the Upper Cretaceous matrix. The breccias represent talus falls or debris flows (the soft matrix, if present, was washed away during the coring process), that derive from the steep, upper parts of the Mazagan Escarpment. They give us samples of the rocks cropping out there, and tell us that at least by Tithonian/Berriasian time (based on calpionellids) there was an open-water facies being deposited there, while a shallow-water platform lay a little farther landward. They also suggest a change in oceanographic conditions along the Mazagan Escarpment. Perhaps the unconformity at the base of the lowest breccia, which represents a few million years of time (late Serravallian-early Tortonian), signifies a time of strong thermohaline currents that removed soft sediments from the Escarpment, oversteepening it and preparing the slope for mass wasting.

The normal sediment, between and above the breccia layers, is burrowed, clayey, yellowish brown foraminiferal-nannofossil ooze, with about $50 \%$ calcium carbonate near the base of the unit, increasing to $60-75 \%$ in the middle and decreasing to only about $40 \%$ near the top. About $5 \%$ terrigenous silt and trace amounts of glauconite occur throughout the unit. The rate of sedimentation was about $25 \mathrm{~m} / \mathrm{m}$.y., or $3 \mathrm{~g} / \mathrm{cm}^{2}$ per $10^{3} \mathrm{yr}$.

\section{Site 546}

This site is about $15 \mathrm{~km}$ west of Site 544 , on a diapiric salt intrusion. The hole was designed to test whether the structure was indeed a salt diapir and not another granitic fault block, similar to the one drilled at Site 544: the distinction is not easy to make on seismic reflection records. The site was chosen to make possible a "safe" test, that is, at a place where hydrocarbons would not be encountered. The acoustic basement appears to crop out at the seafloor only a few kilometers away, and the sediment cover was estimated to be only about $200 \mathrm{~m}$ thick at the chosen site.

Drilling proved the presence of a salt diapir. The salt was cored to a depth of $36.5 \mathrm{~m}$ below the overlying Neogene sediments, and the cores showed layered salt rock, dominantly halite, representing the top of the diapir shown on geophysical records. An age of Rhaetian to Hettangian is suggested by palynomorphs (Fenton, this volume; but see contrasting isotopic evidence from Holser et al., discussed later).

The salt cores were studied in detail by Holser et al. (this volume). The salt rock is mainly halite, color banded on a scale of 0.5 to $3 \mathrm{~cm}$ in shades of reddish brown and gray green. The colors are caused mainly by silt and clay impurities (quartz, illite, kaolinite, illite-smectite). Anhydrite is present (up to about $5 \%$ ), especially in the greenish layers. Potash minerals include carnallite, sylvite, and polyhalite in amounts up to a few percent in some samples.

The salt rock has a cataclastic texture of lenticular small grains of halite wrapping around augen of clear halite $1-3 \mathrm{~cm}$ in diameter, with crushed corners. The cataclastic schistosity and the clay-halite bedding are dom- inantly horizontal, though dips to $60^{\circ}$ occur at a few levels, mainly in potash-rich beds.

Analyses of bromide from the salt cores yield values "typical for a dominantly marine evaporite, deposited in moderately shallow brine, that, however, was not repeatedly dessicated" (Holser et al., this volume).

Holser et al. also report (this volume) stable-isotope ratios for sulfur and oxygen, which they believe indicate derivation from seawater of Permian to Early Triassic age, based on an empirical age curve compiled by Claypool et al. (1980).

Neogene sediments totalling about $155 \mathrm{~m}$ in thickness lie directly on the salt rock. The lower $28 \mathrm{~m}$, of middle Miocene age, consist of greenish nannofossil claystone, which in the basal meter or two is somewhat reddish and sandy, and includes a layer of coarsely crystalline anhydrite about $4 \mathrm{~cm}$ thick - the only trace of a caprock. This lower unit contains reworked Early Cretaceous and Late Jurassic microfossils, presumably washed out of other beds brought to the seafloor by diapirism.

An unconformity spanning the Tortonian Stage separates the lower unit from the upper unit, $127 \mathrm{~m}$ thick and of late Miocene to Recent age, of yellowish brown slightly clayey foraminiferal-nannofossil ooze. The rate of accumulation of the upper unit was about $2 \mathrm{~g} / \mathrm{cm}^{2}$ per $10^{3} \mathrm{y}$.

Diffusion of salt upward from the diapir is shown by the steady increase in pore-water salinity in the Neogene sediments, from normal seawater at the surface to $194 \%$ just above the salt rock.

\section{Site $\mathbf{5 4 7}$}

This site is located about $5 \mathrm{~km} \mathrm{NE}$ of Site 544 , on the same high-standing fault block but on its eastern slope, at a lower structural position. Drilling established not only the presence of a much thicker and more complete stratigraphic sequence than at Site 544, but also documented strong facies contrasts among the three sites (544, $545,547)$ where we cored Jurassic sequences.

Crystalline basement rocks were not reached by the drill at Site 547, owing to lack of time. The seismic records close to the site show a diffraction-like pattern about 1.00 to $1.05 \mathrm{~s}$ beneath the seafloor that possibly indicates the top of basement. Using a plausible interval velocity for the lowest sediments $(2.5 \mathrm{~km} / \mathrm{s})$, the calculated depth to basement is 1030 to $1090 \mathrm{~m}$. The total depth of the hole was $1030 \mathrm{~m}$, suggesting that only a little further effort is required to deepen this hole into basement.

\section{Upper Triassic-Jurassic Rocks}

The lowest $97.5 \mathrm{~m}$ of sedimentary strata at Site 547 consists mainly of grayish red and gray arkosic sandy mudstone with scattered concretionary patches of dolomite and a few veins of gypsum. Pebbles of dolomite occur, with granitic granules in the lowest core recovered. Fenton (this volume) reports poorly preserved nonmarine palynofloras from this unit that indicate an age somewhere in the range Rhaetian to Hettangian, and also indicate that reducing conditions suitable to preserve unoxidized kerogen existed from time to time in an otherwise strongly oxidizing environment that destroyed organic 
matter. The gypsum and dolomite suggest at least seasonal aridity. Taken together, the lithologic and floral data suggest a low-lying coastal plain, with poorly drained swampy and lacustrine areas, in a seasonally arid climate. Granitic bedrock was prevalent in the source areas.

The nonmarine beds are overlain abruptly by Jurassic carbonate rocks, totalling about $159.5 \mathrm{~m}$ in thickness. The lower $122.5 \mathrm{~m}$ is Early Jurassic (late Hettangian or early Sinemurian to late Pliensbachian in age) and the uppermost $18 \mathrm{~m}$ is Late Jurassic (Oxfordian-Tithonian) in age. Middle Jurassic (Bajocian-Callovian) fossils occur at one level in the intervening $19 \mathrm{~m}$. Because many of the datable fossils occur in breccias, and because such a large proportion of the Jurassic section is occupied by breccias, grainstones, and other transported materials, age assignments remain uncertain.

The basal $8 \mathrm{~m}$ of carbonate includes laminated strata that resemble stromatolites, along with fenestral boundstone and breccias of stromatolites. Sheet cracks in the boundstone contain calcitic pseudomorphs of undeterminable evaporite minerals (see Steiger and Jansa, this volume, and for an alternate, deeper-water interpretation, Bernoulli and Kälin, this volume). The breccia beds suggest high-energy conditions associated with marine transgression, perhaps over a tidal-flat environment.

The next overlying beds, about $78 \mathrm{~m}$ thick, consist of nodular peloidal wackestone and breccia with pelagic fossils-radiolarians and Schizosphaerella (Kälin and Bernoulli, this volume)-indicating a very sudden deepening of water, probably to a depth of more than $100 \mathrm{~m}$. The breccia beds, which are in the main simply beds of redeposited nodules, suggest deposition on or at the base of a slope. Intercalated in the nodular limestones are thin bands of black shale, one of which is about $25 \mathrm{~cm}$ thick and contains nearly $9 \%$ organic carbon, mainly from nonmarine plant sources (see Rullkötter et al., this volume). This nodular limestone unit ranges from late Sinemurian to early Pliensbachian in age, giving an average sedimentation rate of about $16 \mathrm{~m} / \mathrm{m}$.y. or an accumulation rate of about $4.0 \mathrm{~g} / \mathrm{cm}^{2}$ per $10^{3} \mathrm{yr}$.

Above the nodular limestone is about $24 \mathrm{~m}$ of sandy limestone breccia, of probable late Pliensbachian age. The thick $(0.2-1 \mathrm{~m})$ breccia layers contain clasts of a great variety of limestones, for example, sponge and radiolarian-rich wackestone, pelmicritic crusts, red quartzfeldspar sandstone, and bioclastic wackestone, as well as bioclasts of mollusks, foraminifers, ammonites, and echinoderms. These slope deposits indicate that relatively shallow-water environments were present upslope from Site 547, and that erosion had exposed older red beds. The accumulation rate of these beds was at least as fast as the underlying nodular limestone $\left(4.0 \mathrm{~g} / \mathrm{cm}^{2}\right.$ per $10^{3} \mathrm{yr}$.) and was probably much faster, judging by the coarse textures.

Above the breccias is about a meter of interbedded reddish and greenish calcisiltite and then a remarkable sequence only about $5 \mathrm{~m}$ thick of about a dozen cycles, each consisting of pelagic wackestone breccia overlain by pelagic wackestone (Core 547B-11). The breccia layers are generally capped by crusts and the irregular interstices filled with multigenerational internal sediments and cements. Steiger and Jansa (this volume) invoke selective early lithification of a burrowed pelagic wackestone, removal by currents of unlithified parts to form a honeycomb breccia, internal sedimentation in the open spaces, and then crust formation. Jansa et al. (this volume) offer a contrasting interpretation: the breccias represent debris flows, with later infilling of open pores by internal sediments. Bernoulli and Kälin (this volume) also regard these breccias as products of mass flows or rock falls. The numerous hardgrounds in the sequence indicate low net accumulation rates. Although much of the Middle Jurassic may be represented here, no age-diagnostic fossils were discovered in this unit, which is overlain by $3.5 \mathrm{~m}$ of red and green nodular limestone containing foraminifers with an age range of Bajocian to Callovian (Riegraf et al., this volume).

The uppermost Jurassic limestone beds, about $33.5 \mathrm{~m}$ in thickness, consist of alternating units of ungraded limestone breccia and nodular limestone ranging in age from Oxfordian to late Tithonian/Berriasian. The breccia layers include resedimented shallow-water and deeperwater platform materials, similar to the in situ Jurassic platform limestone at Site 544. The nodular limestone beds, which contain pelagic bivalves (probably Callovian to Oxfordian), protoglobigerinids (probably mainly Oxfordian), Saccocoma (Kimmeridgian), and calpionellids (Tithonian-Berriasian), in ascending order, were probably deposited in water at least a few hundred meters deep.

Near the very top of the sequence, graded limestone turbidite layers containing resedimented platform debris are conspicuous.

The average sedimentation rate for the Upper Jurassic sequence was about $2 \mathrm{~m} / \mathrm{m}$.y., or about $0.5 \mathrm{~g} / \mathrm{cm}^{2}$ per $10^{3} \mathrm{yr}$.

\section{Cretaceous Rocks}

A thin, condensed unit of Early Cretaceous age with breccia and turbidite layers caps the Jurassic section. The highest limestone breccia layer is at a depth of $772.5 \mathrm{~m}$, and the highest Jurassic (late Tithonian-Berriasian) calpionellids are at $773.9 \mathrm{~m}$. Cretaceous foraminifers and nannofossils of Valanginian-Hauterivinian age occur at $773.4 \mathrm{~m}$, and Albian foraminifers occur at $772.8 \mathrm{~m}$, just below the topmost occurrence of limestone breccia. We interpret these uppermost breccias as a highly condensed sequence, whose upper part has been resedimented into the base of the thick, overlying middle Cretaceous unit.

The unconformity spans the interval from the middle or upper Albian to nearly the top of the Jurassic, with a maximum of only a meter's thickness ascribable to preAlbian, post-Berriasian strata.

Middle Cretaceous strata are about $351 \mathrm{~m}$ thick at Site 547. The beds range in age from late Albian (Biticinella breggiensis Zone) at the base to middle to late Cenomanian (Rotalipora cushmani Zone) and consist of a monotonous sequence of greenish, more or less calcareous claystone, with subordinate amounts of intraformational flat-pebble claystone conglomerate and mudstone. Burrows are ubiquitous, but laminated mudstone with molluscan shell fragments occurs as a minor litho- 
logic type. Clay layers are generally dominated either by waxy clays, consisting of kaolinite and illite, or by swelling clays, which contain smectite-illite in addition. Calcium carbonate content, imparted by nannofossils and well-preserved planktonic foraminifers, averages about $25 \%$. Organic carbon content is typically $0.5-1 \%$. Minor slumps are common, and, taken together with the intraformational debris-flow deposits, indicate deposition on a slope, with much resedimentation and mass wasting. The average rate of sedimentation was about $29 \mathrm{~m} /$ m.y., or about $5 \mathrm{~g} / \mathrm{cm}^{2}$ per $10^{3} \mathrm{yr}$.

Turonian through Santonian strata are missing at Site 547, and Upper Cretaceous strata are represented at Site 547 by about $60 \mathrm{~m}$ of burrowed greenish gray nannofossil chalk, commonly with slump structures, and of nannofossil chalk conglomerate and breccia, ranging in age from middle Campanian to late Maestrichtian. We interpret the sequence as largely the product of the redeposition of sediments first deposited on the Mazagan Slope in a well-oxygenated environment, and then carried to the base of the slope by mass movements. The average rate of sedimentation lies in the range $6-20 \mathrm{~m} /$ m.y., or $0.7-2.4 \mathrm{~g} / \mathrm{cm}^{2}$ per $10^{3} \mathrm{yr}$.

\section{Cenozoic Rocks}

The upper $372 \mathrm{~m}$ of the stratigraphic column is Cenozoic. It is divided by three unconformities into a lowest unit, about $96 \mathrm{~m}$ thick, of latest Cretaceous-early Paleocene to late Paleocene or earliest Eocene age; a unit about $71 \mathrm{~m}$ thick, of late Eocene to early Oligocene age; a unit about $64 \mathrm{~m}$ thick, of early to middle Miocene age; and an upper unit, $141 \mathrm{~m}$ thick, of late Miocene to Pleistocene age.

The lowest unit includes the oldest Paleocene Globigerina eugubina zone. Because the uppermost Cretaceous and lowermost Tertiary strata occur in an interval characterized by redeposition, these cores do not appear promising for detailed studies of the era boundary.

The Paleocene beds consist mainly of bioturbated greenish gray nannofossil claystone and chalk, and contain minor chert nodules and radiolarians. This is the most siliceous part of the whole column drilled at Site 547. Siliceous biogenous material is commonly in excess of $20 \%$ in the lower part of the unit. Organic carbon content is mainly only a few tenths of $1 \%$. Calcium carbonate content is typically in the range $35-60 \%$. Nannofossils are commonly recrystallized and foraminifers are rare but well preserved. Unique to this unit are volcanic glass shards, which are present in small amounts. In the uppermost part of the unit sheared and contorted bedding is common. Sedimentation rates averaged about $7 \mathrm{~m} / \mathrm{m}$.y., or $1 \mathrm{~g} / \mathrm{cm}^{2}$ per $10^{3} \mathrm{yr}$. This unit was deposited on the Mazagan Slope under conditions of moderately high fertility, but organic matter was poorly preserved because of the oxidizing conditions associated with relatively slow accumulation rates.

The age difference of the beds across the unconformity that separates the upper Paleocene (or lower Eocene) beds from the upper Eocene is about 15 m.y., and the unconformity may represent an erosional rather than simply a nondepositional surface. The overlying upper Eo- cene beds include many slumped beds and layers of intraformational claystone breccia. A few chert clasts occur in the breccias, which represent debris flows. The redeposited and slumped Eocene beds are about $45 \mathrm{~m}$ thick and are overlain by about $26 \mathrm{~m}$ of greenish nannofossil chalk of late Eocene to Oligocene age. The average rate of sedimentation for the $71 \mathrm{~m}$ of beds was about $14 \mathrm{~m} / \mathrm{m}$.y., or about $2 \mathrm{~g} / \mathrm{cm}^{2}$ per $10^{3} \mathrm{yr}$.

The overlying lower and middle Miocene strata are separated from the Eocene-Oligocene beds by an unconformity representing 6 to $10 \mathrm{~m}$.y. Much of the Oligocene may be missing. The contact is sharp and is marked by a lithologic change from firm greenish nannofossil clay below to olive gray, slightly clayey nannofossil ooze above. Burrows filled with the overlying sediment occur in the upper few centimeters of the lower unit.

A few meters of lower Miocene ooze are overlain, probably across a small unconformity, by middle Miocene ooze about $60 \mathrm{~m}$ thick. The ooze is greenish to light olive gray, burrowed, and generally contains about $30 \%$ terrigenous clay material, plus trace amounts of quartz and feldspar silt. Glauconite is persistently present at the $1 \%$ level. The depositional milieu was hemipelagic, above the foraminiferal lysocline, in a deep bathyal, low-energy environment, on the lower part of Mazagan Slope. The rate of sedimentation for the middle Miocene beds was about $13 \mathrm{~m} / \mathrm{m} . \mathrm{y}$., or $1.8 \mathrm{~g} / \mathrm{cm}^{2}$ per $10^{3} \mathrm{yr}$.

The uppermost upper Miocene-Recent unit rests unconformably on the middle Miocene. Some or all of the Tortonian Stage (11.5-6.6 m.y. ago) is missing. The contact is sharp, and is marked by a layer of foraminiferal sand and glauconite, suggesting slow accumulation and winnowing by currents. The upper unit consists of pale yellowish brown, slightly clayey foraminiferal-nannofossil ooze, with trace amounts of quartz and feldspar silt and silt-sized dolomite rhombs. Carbonate content averages around $40 \%$. The sedimentation rate for this unit was about $20 \mathrm{~m} / \mathrm{m}$.y. or $2-6 \mathrm{~g} / \mathrm{cm}^{2}$ per $10^{3}$ yr. The environment was on the slope, oxidizing, and above the foraminiferal lysocline, with terrigenous sediment from the continent, supplied perhaps partly by the wind.

\section{CONCLUSIONS: A MODEL FOR THE EVOLUTION OF THE MAZAGAN SECTOR OF THE MOROCCAN MARGIN}

By combining the results of (1) drilling during Leg 79 and other drill and dredging information from the Morocco margin; (2) seismic, magnetic, and gravity data; (3) data on the regional land geology onshore in the Morocco region; and (4) drilling, geophysical, and geologic data from the conjugate-margin region of North America, we can make some general conclusions about the evolution of the Moroccan margin and its relation to the opening of the central Atlantic Ocean.

The overall pattern is one of progressive foundering of the margin, from the west toward the east, that is, from the area of the nascent oceanic basin toward the continent. This process probably began well back in the Triassic, although in the immediate Mazagan area the oldest events are datable only to the Rhaetian Stage of the latest Triassic or the Hettangian Stage of the earliest 
Jurassic. Faulting, rifting, and rotation of crustal blocks continued intermittently at least to the end of the Jurassic, and subsidence probably continues to the Recent. Extensional tectonic activity, manifested in block faulting and accelerated subsidence, appears to us to have been most intense in the Rhaetian-Hettangian and in the early part of the Late Jurassic, keeping in mind that at least some faulting doubtless continued on a smaller scale at other times.

In the following section, we set out a sequential history, emphasizing the tectonic control on subsidence and paleogeography. The sequence is illustrated in a series of diagrammatic cross sections (Fig. 13), showing the inferred geologic relations at four different significant times in the past, as well as the situation today. We also show corresponding paleogeographic maps for these times (Figs. 14, 15, 16, 17) in the immediate area of Leg 79 operations. Finally, we have drawn a set of "geohistory" curves for three of the drill sites (Fig. 18).

\section{Rhaetian Stage (last panel in Fig. 13, Fig. 14)}

Evidence from Site 546 and from the reflection seismic data shows that during Rhaetian, and perhaps Hettangian time, salt was being deposited in a marine basin that extended about $100 \mathrm{~km}$ westward from the foot of the continental slope along the Mazagan margin. Similar salt deposits in a comparable position at the foot of the conjugate Nova Scotia margin suggest a basin about $150-200 \mathrm{~km}$ wide, lying at or even possibly a little below global sea level. The salt has been carried upward in diapiric structures, and these structures are crudely aligned parallel to the trend of the margin, suggesting that there were elongate basins in which salt accumulated, separated by structural highs. On the other hand, some of the half-graben basins discernable on the seismic profiles show no effects of salt diapirism, suggesting that continental beds, probably similar to those drilled at Sites 544 and 547, partly fill some basins. We speculate that the red beds may also underlie the salt.

The paleontological evidence from palynomorphs in continental beds at Site 547 (Fenton, this volume) point to a latest Triassic age. On the other hand, Holser et al. (this volume) note that the sulfur isotopic ratios in minerals associated with the halite at Site 546 are quite different from the ratios found in Rhaetian-Hettangian salt deposits elsewhere in the world, but are within the range of values found elsewhere in salt of Late Permian or earliest Triassic age. They conclude that the salt is therefore of this older age. We cannot reconcile these two conflicting lines of evidence, although we do not accept that the empirical isotopic curve of Holser is yet firmly established as a dating method. Holser et al. do not evaluate the isotopic-fractionation consequences of the possible impoverishment of Moroccan Basin waters by precipitation of anhydrite in Tethyan basins connecting an isolated Atlantic to the world ocean. Although it is far simpler to construct a geologic history accepting the Rhaetian age of the salt, it is possible, given the virtual absence of evidence from the Atlantic margins on Permian and Early Triassic tectonic and sedimentation pat- terns, to place a rift basin in this position at that early time.

Landward of the rifted salt-basin province, seismic sections show a fault-block topography, probably with continental red beds similar to those drilled at Sites 544 and 547 in the deeper half-grabens. Such Late Triassic sediment-filled grabens are also known from onshore Morocco. Site 544 was probably near the uptilted western edge of a fault basin and the red beds there include mudflow deposits. At Site 547, gray colors and the good preservation of palynomorphs suggest at least seasonal reducing conditions, as for example in bogs or ponds. Jansa et al. (this volume) believe these grayish beds are lacustrine. This site was at a lower elevation than Site 544 , and perhaps was near sea level.

Farther landward, we show (Fig. 13, last panel) some fault blocks as being eroded. Seismic data suggest little or no pre-Jurassic carbonate sediment on these blocks. The maximum elevation shown in Figure 13 for the Rhaetic is about $1000 \mathrm{~m}$ above sea level. This figure is conservative, but we see no compelling reason in our data to make it higher.

We also draw the salt basin as lying exactly at (global) sea level. Bernoulli and Kälin (this volume) suggest that the salt was deposited in an isolated basin below global sea level, and that the rapid deepening recorded by pelagic fossils in the lower parts of the overlying Jurassic limestone was due to sudden filling of the basin to normal global sea level.

From a tectonic point of view, a main feature of the model Rhaetian cross section is the large magnitude of fault displacements (and probably rotation and crustal thinning) beneath the salt basin, and the smaller displacements to the east.

\section{Liassic (fourth panel on Fig. 13, Fig. 15)}

Subsidence continued during the Liassic, but faulting was not so prevalent or important as during red bed and salt accumulation. Site 544 remained above sea level, but nearby Site 547 subsided to depths of at least one or two hundred meters by Sinemurian time, and probably continued to subside even farther all during the early and middle Liassic. The slope between Sites 544 and 547 probably steepened a little, perhaps by rotational movements on the fault west of Site 544. The waters at Site 547 were probably rather poorly ventilated, as evidenced by the repeated occurrence of black shale layers in the hemipelagic rocks.

By late Pliensbachian time, a shallow-water platform had established itself somewhere upslope and not far from Site 547: shallow-water clasts rolled down to Site 547 . We suggest narrow banks both east and west of the site.

We place the Liassic shoreline only about $5 \mathrm{~km}$ southeast of Site 547 (i.e., seaward of Site 545), and from here eastward, the region was mainly one of low relief $(\sim 500$ $\mathrm{m})$, close to sea level, and was either being eroded or was the site of thin nonmarine alluvial deposition.

We cannot say for certain from the drilling or seismic evidence in the Leg 79 area whether there was any sea- 

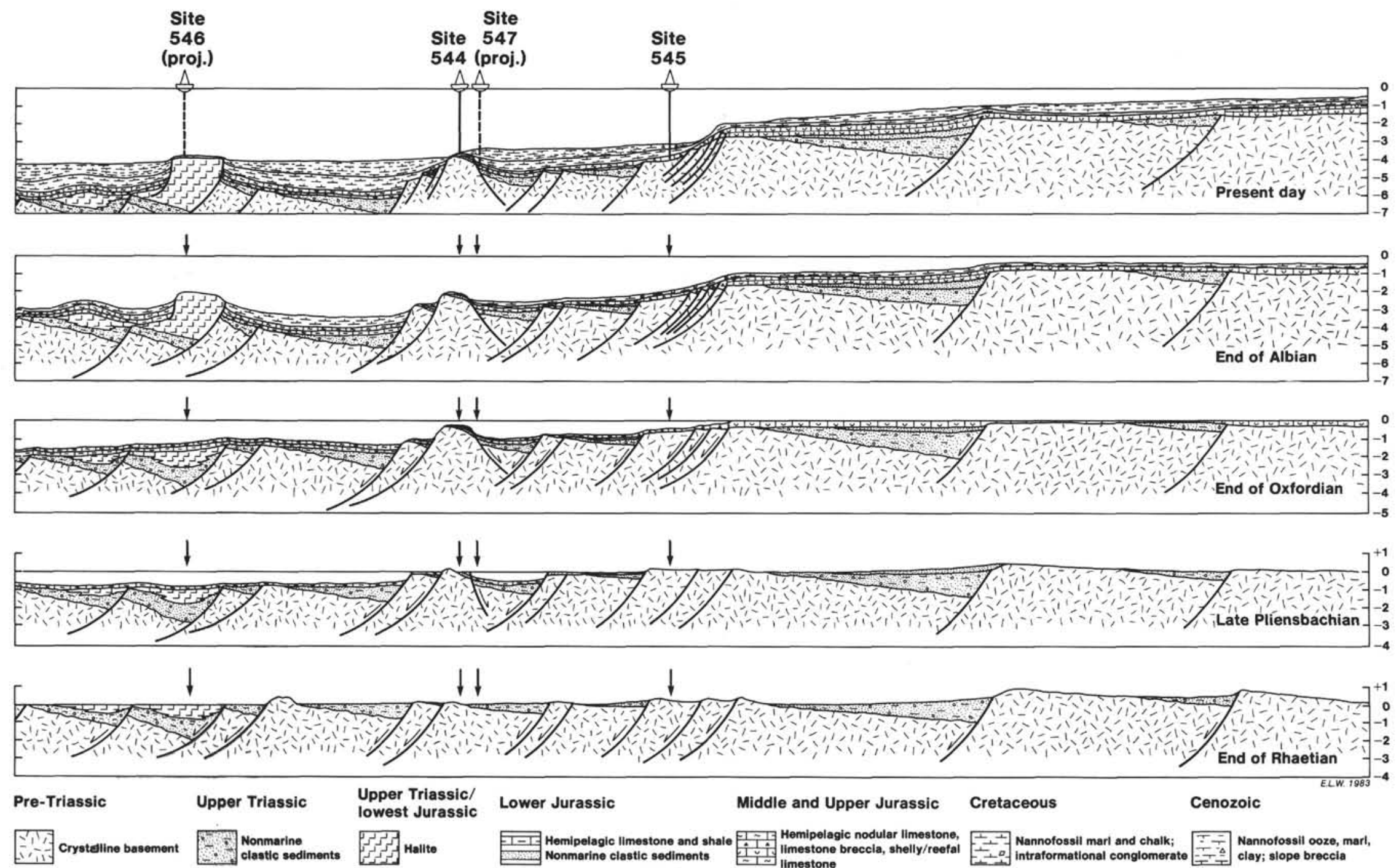

Figure 13. Diagrammatic cross sections at five stages in the geological evolution of the Mazagan continental margin. There is no vertical exaggeration. The location of the cross section is shown on the paleogeras how the salt dicos structural features and formation thicknesses are taken mainly from the seismic data. The paleodepths are inferred from the facies successions in the drill holes, from dredges and CYAMAZ samples, using the "geohistory" diagrams (Figure 18) to estim the seismic data. The paleodepths are inferred from the facies successions in the drill holes, from dredges and CYAMA panel: Present-day. Second panel: End of Albian time ( $\sim 100$ m.y.). Third panel: End of Oxfordian time ( $\sim 143 \mathrm{~m} . \mathrm{y}$.$) . Fourth panel: late Pliensbachian time ( \sim 180 \mathrm{~m} . \mathrm{y}$.$) . Fifth panel:$ End of Rhaetian time ( 192 m.y.). 


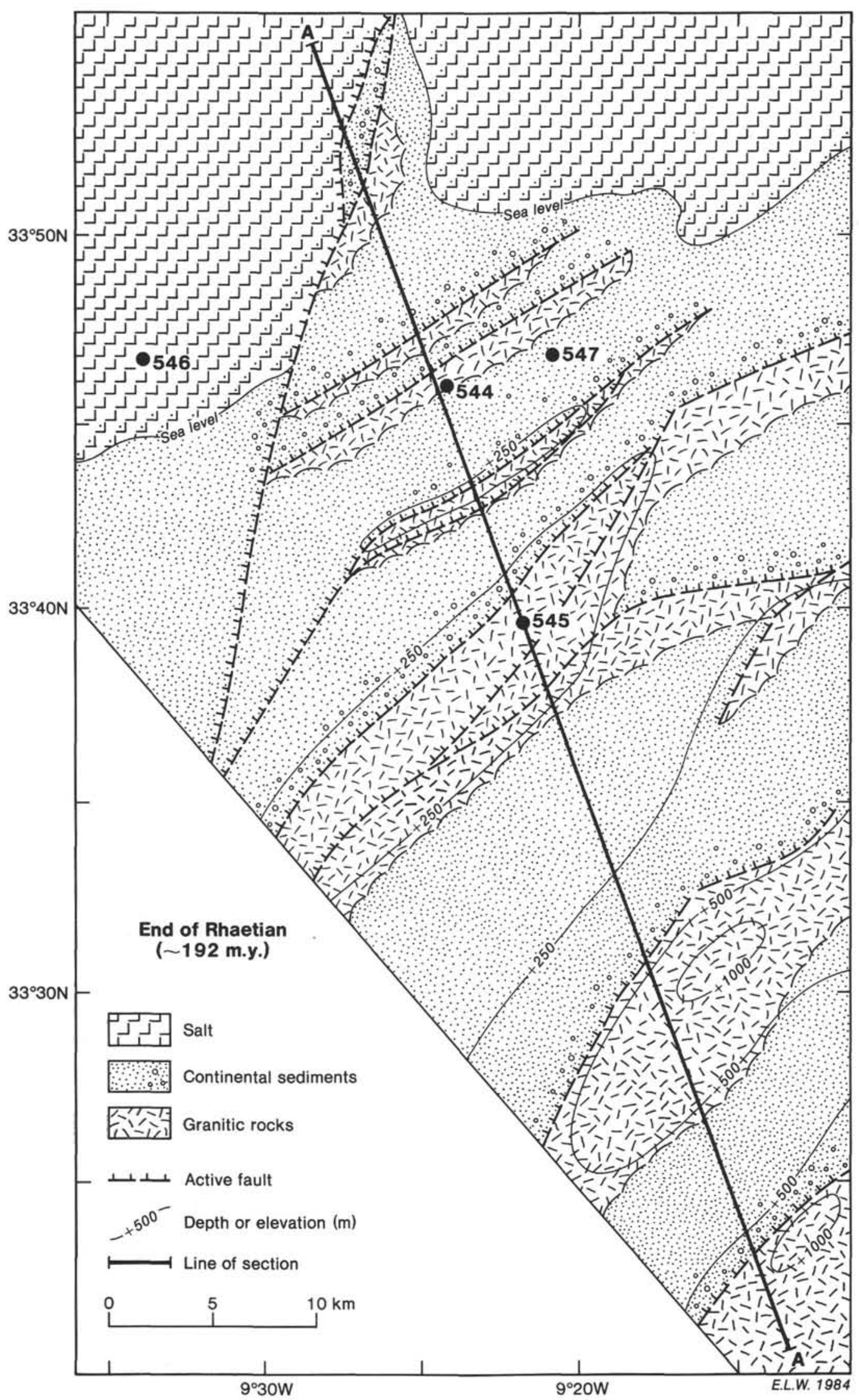

Figure 14. Paleogeographic map showing sedimentary facies, outcropping granitic basement, active faults, and elevation contours at the end of Rhaetian time. 


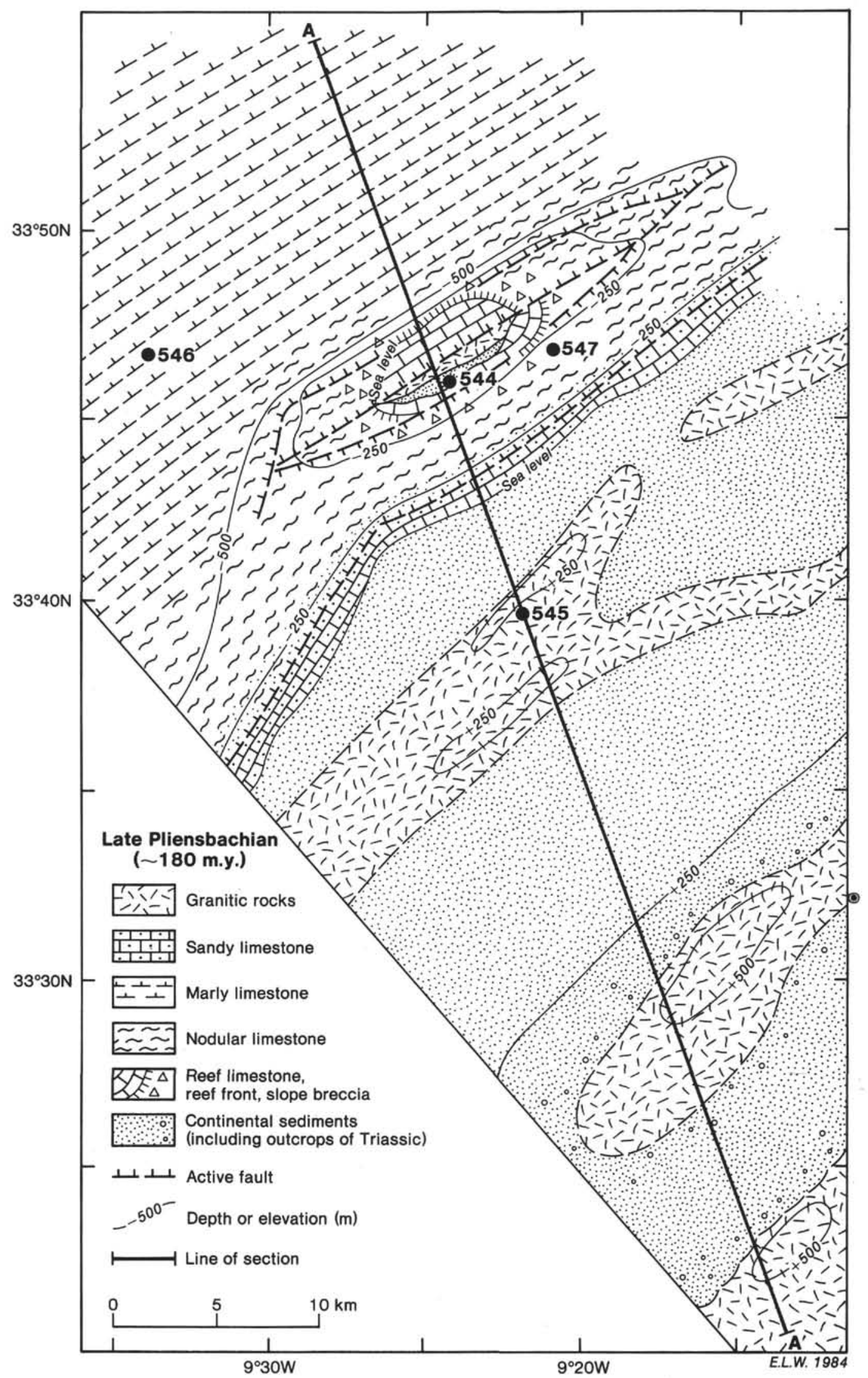

Figure 15. Paleogeographic map showing bathymetry, sedimentary facies, outcropping older rocks, active faults, and depth/elevation contours in Late Pliensbachian time. 


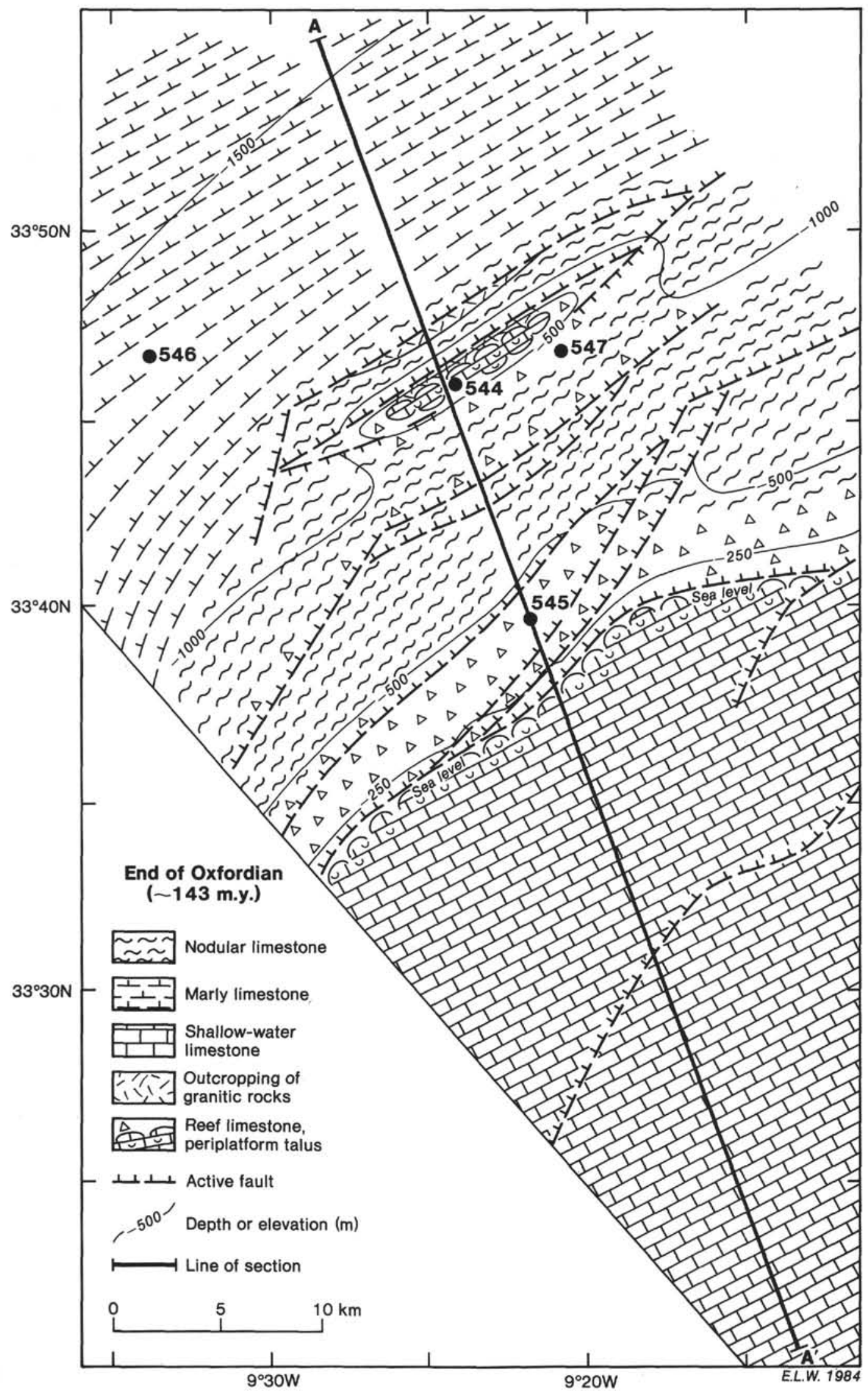

Figure 16. Paleogeographic map showing sedimentary facies, outcropping older rocks, active faults, and depth contours at the end of Oxfordian time. 


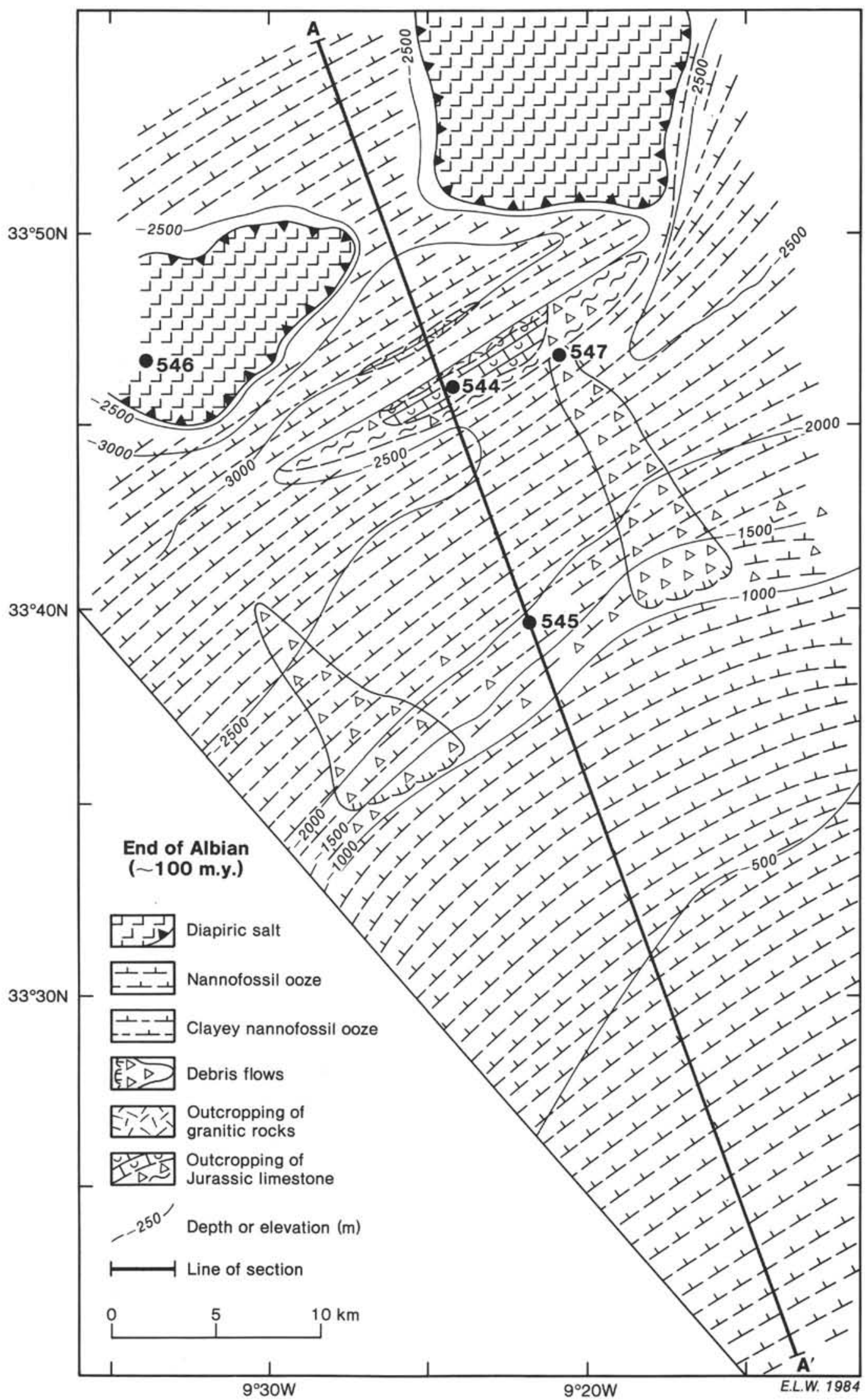

Figure 17. Paleogeographic map showing sedimentary facies, outcropping older rocks, active faults, and depth contours at the end of Albian time. 


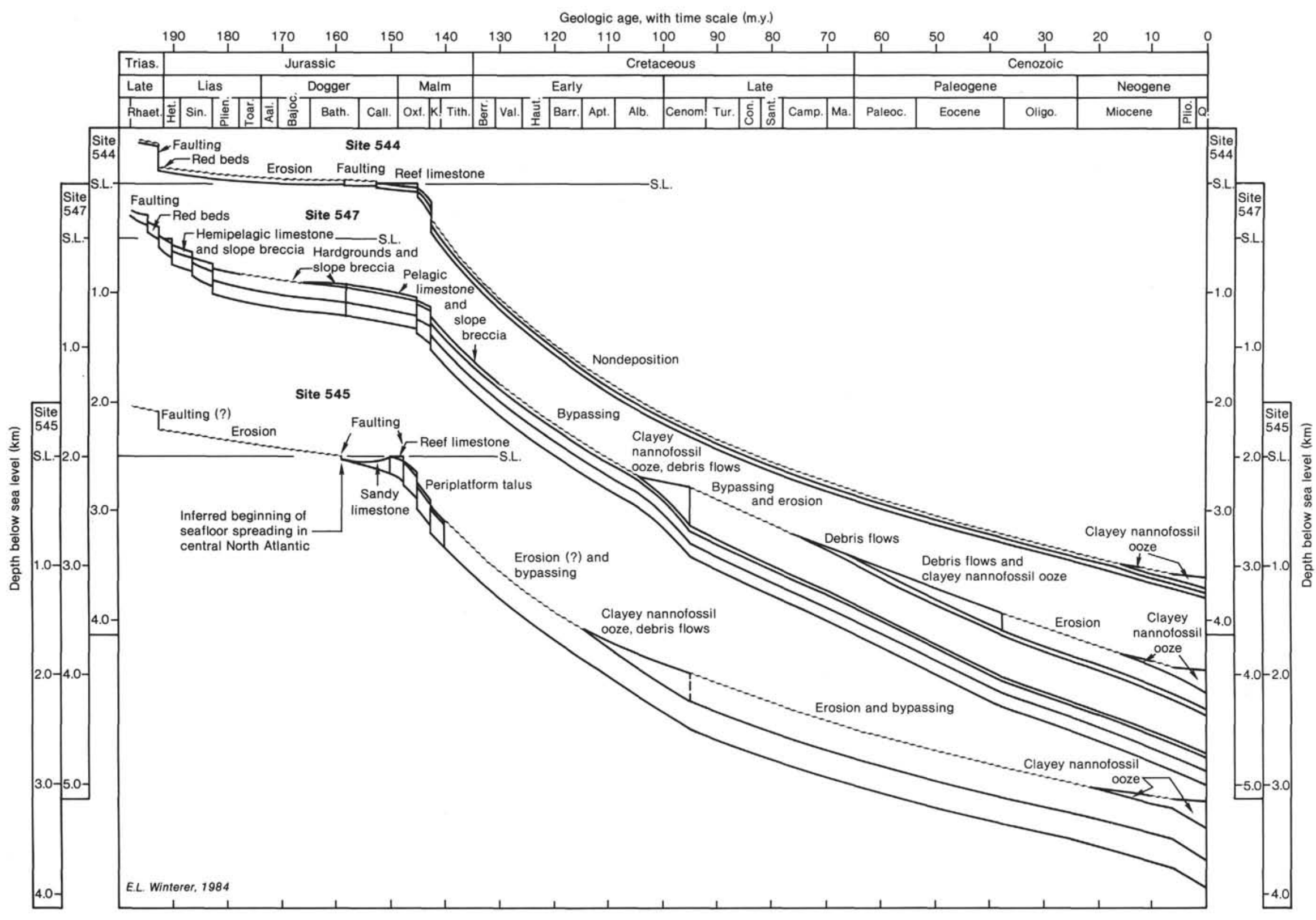

Figure 18. Age-versus-depth ("geohistory") diagram inferred for Sites 544 (upper diagram), 547 (middle diagram), and 545 (lower diagram). Note that each diagram has its own depth scale. The time scale at the bottom is the van Hinte (1976) scale. Subsidence curves constrained by sea-level crossings and present-day depths. Exponential subsidence curves are assumed where facies data do not constrain the depths. Isostatic (Airy) corrections made for sediment loading. Wavy lines denote erosion, bypassing, or nondeposition. 
floor spreading in the Central Atlantic at this time. We lean toward there not having been any, because subsidence rates, as deduced from the successions drilled at Sites 544 and 547 (Fig. 18) were low, and because we do not see a place seaward of the salt province, on oceanic crust, to put Early Jurassic crust. We defer this argument until a later section, when we discuss Callovian-Oxfordian events and the date of earliest seafloor spreading.

\section{Middle Jurassic}

Only at Site 547 is there good evidence from fossils that strata of Middle Jurassic age may be present in this region. Those fossils (foraminifers) occur in only one sample and give an age of Bajocian-Callovian. At Site 545 , fossils in the lowest $36 \mathrm{~m}$ of beds cored constrain their age only to Middle or Early Jurassic. On the other hand, the "filaments," or small pelagic bivalves that occur at both Sites 544 and 547, suggest Middle Jurassic, based on the most common levels of abundance of these fossils in western Tethys. We conclude that Middle Jurassic strata, if present at all, are very thin: this was a time of subsidence, but not of sedimentation. In contrast, Jansa and Steiger (this volume) assign $30 \mathrm{~m}$ of reddish breccia and sandstone to the Middle Jurassic at Site 547, even though these strata (Cores 547B-11 to 547B-14) are dated as Pliensbachian by fossils. Taken together with the sandy beds of possible Middle Jurassic age at Site 545 , they argue for a mid-Jurassic time of regression.

\section{Oxfordian (third panel on Fig. 13, Fig. 16)}

A great change in the paleogeography began about Oxfordian time. On a regional scale, a marine transgression extended farther inland onto the Moroccan mainland than at any previous time in the Jurassic. The transgression-the so-called "Atlantic transgression"-has been remarked all around the North Atlantic (see review in Lancelot and Winterer, 1980), although there is disagreement as to the exact timing in different areas. Part of the problem stems from the scarcity of good zonal fossils in most sections, and the Mazagan area is no exception. One Oxfordian ammonite was identified from shallow-water sediments at Site 545 , but most of the post-Liassic platform limestone can be dated only as "Late Jurassic." Even this loose designation may include the later part of the Middle Jurassic. We thus use the term Oxfordian here in a broad sense, and recognize that post-Liassic carbonate platform development may have begun a bit earlier or later in various parts of the Mazagan area. We associate the change in paleogeography and the widespread development of carbonate banks with the inception of fairly rapid seafloor spreading in the central North Atlantic, and we therefore tend to believe the age of the base of the limestones may be Callovian, or possibly even Bathonian, for reasons we review below. On the reconstructions and geohistory diagrams we stick as closely as possible to the evidence from datable fossils.

At Site 544, Oxfordian limestone of moderate-depth facies $(\sim 100 \mathrm{~m})$ directly overlies the red beds, and suggest rapid subsidence. At Site 545, where we did not drill to basement, the oldest beds cored are offshore sandy limestones overlain by Oxfordian shallow-water platform limestone. The platform rocks are succeeded upward by periplatform breccia, suggesting a submergence at Site 545 and an eastward retreat of the front of the active platform (Fig. 16). We associate this event with a renewal of faulting along the Mazagan Escarpment, along the same structural lines active during the earlier Rhaetian faulting. The subsidence at Site 545 was probably rapid (Fig. 18): the breccia is overlain unconformably by deep-water middle Cretaceous rocks, with no transition facies. We do not know the age span of the rocks at Site 545 above the Oxfordian ammonite, but it would take only a few million years at a modest subsidence rate, combined with isostatic loading, for the $108 \mathrm{~m}$ of carbonate rocks above the ammonite to accumulate.

An upper bound on the time of platform drowning along the Mazagan Escarpment is provided by the limestone clasts in the Miocene at Site 545. These clasts were certainly derived from the steep escarpment immediately east of the drill site. They include clasts of limestone with both shallow-water grains and more open-sea calpionellids in the matrix, suggesting that the water was already at least a few hundred meters deep, but that a shallow-water bank lay not far away to the east, perhaps on the fault block about $10 \mathrm{~km}$ southeast of the edge of the Mazagan Plateau (Fig. 16). The age of the calpionellids is late Tithonian/Berriasian.

As to the broader question of the age of earliest seafloor spreading in the central Atlantic, we must turn to data from Site 534, in the western North Atlantic off the southeastern coast of the United States, drilled during DSDP Leg 76 (Sheridan, Gradstein, et al., 1983). Site 534 is located on crust of Callovian age, on Magnetic Anomaly M-28. Using the van Hinte (1976) time scale, the data from this site can be used to calculate spreading history, with distances measured along the fracture-zone "flow lines," as follows:

Distance, Site 534 to Anomaly M-22 $=410 \mathrm{~km}$

Distance, M-22 to Blake Spur Anomaly $=490 \mathrm{~km}$

Age of M-22 (Tithonian/Kimmeridgian boundary) $=141 \mathrm{~m} . \mathrm{y}$. (Channell, 1981)

Age of basement at Site 543 (Middle Callovian) $=153 \mathrm{~m} . \mathrm{y}$.

Average halfrate of spreading, M-22 to Site 534 $=\left(410 \times 10^{5}\right) /\left[(153-141) \times 10^{6}\right]=3.4 \mathrm{~cm} / \mathrm{yr}$.

Extrapolated age at Blake Spur Anomaly $=\left(141 \times 10^{6}\right)+\left[\left(490 \times 10^{5}\right) / 3.4\right]=154$ m.y. (latest Bathonian)

This is essentially the same age as that calculated by Gradstein and Sheridan (1983) for the Blake Spur Anomaly.

We can now estimate the crust seaward of Anomaly S-1, at the west edge of the diapiric province off Mazagan. We assume S-1 has the same age as the East Coast Anomaly. To compare rates and distances at Mazagan with those at Site 534, we use the plate rotational model of LePichon et al. (1977). In this model, the distance of the Mazagan margin was about $32^{\circ}$ from the Euler pole of rotation for early central Atlantic opening and Site 534 was about $50^{\circ}$. The amount of crust produced off Morocco during the period 155.4-141 m.y. should 
therefore be: $490(\sin 32 / \sin 50)=339 \mathrm{~km}$. The actual distance from M-22 to S-1 off Mazagan is $410 \mathrm{~km}$ (Fig. 6). There is thus an "excess" of about $70 \mathrm{~km}$ of crust, presumably older than 155 m.y. At the same rotational spreading rate $\left(2.35 \mathrm{~cm} / \mathrm{yr}\right.$. at $32^{\circ}$ from the pole of rotation), the age of the oldest crust would be $155.4 \times 10^{6}$ $+\left(70 \times 10^{5}\right) / 2.35=158.4$ m.y. or late Bathonian, in the van Hinte (1976) time scale. The use of other, more recently proposed time scales (e.g., Gradstein and Sheridan, 1983) does not change the stage assignments, although the absolute ages shift.

The justification for assuming the same spreading rate for all the crust from M-22 to Anomaly S-1 is that reflection profiler records off Morocco show no change in the character of oceanic basement across this region (Figure 19). The basement is, in fact, much smoother (less local relief) than in areas west of Anomaly M-22, on younger crust.

Going back to the region near Site 534, we now can speculate on the origin of the strip of crust between the Blake Spur Anomaly and the East Coast Magnetic Anomaly (the "Inner Quiet Zone"). The width of crust formed during the $3 \mathrm{~m} . \mathrm{y}$. of spreading west of Site 534 before the Blake Spur Anomaly should be $3 \times 10^{6} \times 3.4=102$ $\mathrm{km}$. The width of crust between the Blake Spur and East Coast magnetic anomalies in this area is $210 \mathrm{~km}$, which is essentially twice the required amount. It has been suggested (Vogt, 1973) that the Blake Spur anomaly represents the site of an early ridge-crust jump, and if our reasoning is correct, then the double width of crust would most plausibly be explained by just such a jump, but at a much later time than suggested by Vogt (1973) and Vogt and Einwich (1979), that is, 155 rather than 175 m.y. Sheridan (1983) speculated that this Inner Quiet Zone was produced by rapid spreading just prior to the latest Bathonian. The Morocco data are consistent with Sheridan's interpretation, and suggest that the history of early opening started in the late Bathonian, at rates of about $3.4 \mathrm{~cm} / \mathrm{yr}$. in the southern, and $2.4 \mathrm{~cm} /$ yr. in the northern part of the central Atlantic. After about 3 m.y. of spreading, at about the Bathonian/Callovian boundary, the axis of spreading in the region south of the Norfolk-Cape Blanc Fracture Zone shifted eastward about $100 \mathrm{~km}$, to the ocean/continent boundary on the African side, while in the northern part of the central Atlantic spreading continued without any corresponding shift in the axis of spreading.

We suggest that the initiation of spreading at about the end of Bathonian time reactivated listric faulting in the already thinned continental crust along the west edge of the Moroccan margin, thereby further stretching the crust, especially in the area of the present-day Mazagan Slope, where important new faults developed to block out the Mazagan Escarpment. This faulting and crustal stretching was accompanied by a concomitant increase in subsidence rates.

\section{End of Albian (second panel on Fig. 13, Fig. 17)}

We choose this time to illustrate because it is within the time of rapid accumulation of hemipelagic sediments on the Mazagan Slope. This accumulation began in Ap- tian time and continued until near the close of the Cenomanian-a period of about 20 m.y.

Following the Late Jurassic time of rapid subsidence that drowned the carbonate platforms seaward of the Mazagan Escarpment, subsidence continued, first drowning the region from the outer edge of the Mazagan Plateau back to the structurally high block (the Central Mazagan Block) about $10 \mathrm{~km}$ to the southwest, probably in the latest Jurassic or earliest Cretaceous, and then drowning the structurally high block itself. This latter drowning probably was a little prior to Late Aptian time, and perhaps was associated with the very beginning of hemipelagic sedimentation on the Mazagan Slope. Seismic data suggest perhaps one or two hundred meters of middle Cretaceous sediments over the Central Mazagan Block.

Whether the Early Cretaceous subsidence was accompanied by continued faulting is hard to specify in detail, but as outlined in the discussion of Oxfordian events, we believe the rapid facies changes documented in the core samples and the faults shown on the seismic records point to major faulting during the earlier part of this subsidence, and some of the major fault zones may well have remained intermittently active during the Cretaceous.

The seismic records indicate a regional downlap of the hemipelagic slope deposits, with Aptian and lower Albian beds toeing out onto the Jurassic carbonate platform near Site 545, and upper Albian beds terminating against the structural high seaward of Site 547 . The prevalence of slump structures and other evidences of gravity sliding down the Mazagan Slope during the middle Cretaceous, and the occurrence of similar structures over a broad region to the south of the Mazagan sector, in the Essaouira sector, documented during DSDP Leg 50 (Price, 1980; Lancelot and Winterer, 1980), suggests that some regional tectonic steepening may have taken place during this general time period. Alternatively, the major slope steepening may have been during the time of most rapid subsidence, near the end of the Jurassic, when rotational block faulting resulted in differential rates of subsidence across the Mazagan Slope. During Early Cretaceous times, in areas south of the Mazagan sector, huge quantities of sand were delivered to the Moroccan Basin as turbidites, but only fine silt and mud were delivered during middle Cretaceous time. These muds came to rest on the continental slope rather than being slumped toward the basin. In the Mazagan sector, by contrast, the Early Cretaceous sands either were blocked from the Mazagan Slope, or bypassed it completely. The middle Cretaceous muds then were deposited on an already steep and barren slope, and were subject to slumping and sliding.

Beyond the base of Mazagan Slope, in the Moroccan Basin, the Lower(?) and middle Cretaceous sediments, as judged from the seismic profiler data, are thick and may include turbidite sands that bypassed the Slope.

Halokinesis has strongly affected the middle Cretaceous beds, and the pattern of deformation, including piercing, rim synclines, and pillow development, indicates that upward movement of salt began during Creta- 
ceous time-probably during rapid sediment accumulation when a density inversion could be well established. The Late Jurassic tectonic events probably played a significant role in destabilizing the salt, for example, by rotation along listric faults. The Albian cross section (Plate 13 , second panel) illustrates some of these complexities, with both pillow and piercement structures, and with granitic blocks next to salt domes. These relations can be documented only where a dense network of highquality multichannel seismic data exists. Most "diapiric" structures on the Moroccan margin are not sufficiently documented to distinguish between purely salt structures and structures also involving sialic basement rocks.

Following the Albian, an additional few hundred meters of nearly identical hemipelagic sediment accumulated on the Slope until nearly the end of Cenomanian time. On the Mazagan Plateau, hemipelagic deposition also continued, but at a slower rate.

The middle Cretaceous beds have a rather low organic content (mainly less than $1 \%$; Rullkötter et al., this volume) considering their rather rapid rate of accumulation $\left(3 \mathrm{~g} / \mathrm{cm}^{2}\right.$ per $10^{3} \mathrm{yr}$.). In the middle Albian, one sample of dark shale contained about $3 \%$ organic carbon. There is thus only a subdued reflection in this region of any of the anoxic "events" recorded so commonly in middle Cretaceous beds elsewhere in the world ocean. Leckie (this volume) documents important changes in foraminiferal diversity at this time and suggests these are due to expansion of the oxygen minimum associated with intensified productivity in surface waters.

\section{Late Cretaceous to Recent (first panel on Fig. 13)}

The post-Cenomanian evolution of the Mazagan Slope has been one of relative tectonic quiescence, while sedimentary processes alternated between rapid sediment accumulation by debris flows and slower, hemipelagic deposition. Unconformities, representing times of nondeposition or even erosion, punctuate the record (Figure 12), especially in the Late Cretaceous, late Oligocene, and late Miocene. The sequence records episodic defacing of the Mazagan Slope, with successively older rocks being laid bare: Cretaceous debris flows are essentially intraformational; the Paleogene debris flows carry older Cenozoic and Upper Cretaceous clasts, and the Neogene breccias contain Jurassic limestone clasts. We suggest that this progressive, episodic defacement is due partly to the increasing role of thermohaline boundary currents in sapping the slope sediments near the top of the Mazagan Slope, where the original depositional slope was already abnormally steep because of the structural relief created when the Mazagan Escarpment was blocked out by Late Jurassic faulting. The post-Jurassic cover on this upper part of the Slope has been progressively stripped away, most generally by mass movements, and the eroded sediments transported farther down the slope. The entire Upper Cretaceous and Paleogene section drilled at Site 547, near the foot of the Slope, is missing at Site 545 , near the top. We suggest that the older sediment was once present at Site 545, perhaps in a thinner pocket than at Site 547, but stripped off by debris flows and eroded by thermohaline currents impinging on the slope. Upper Cretaceous sediments are missing also at Sites 415 and 416 , on the continental slope and rise off Morocco, south of Mazagan (Lancelot and Winterer, 1980). An unconformity between lower Miocene and Oligocene strata exists at Site 547, whereas at the other Leg 79 sites lower Miocene beds rest on Mesozoic rocks.

An unconformity separates middle and upper Miocene strata at all four sites drilled during Leg 79. The hiatus omits about $4 \mathrm{~m}$.y. of record, from some place near the base of the Messinian Stage to some place in the upper part of the Serravallian; the Tortonian is absent or is represented only in highly condensed form. An unconformity at this same stratigraphic level is present at Site 397 off Cape Bojador (Salvatorini and Cita, 1979) and Site 367 on the Sierra Leone Rise, and perhaps at Site 369 off Cape Bojador (Lancelot, Seibold, et al., 1978). On the other hand, no such unconformity is present at Site 370/416 in the deep Moroccan Basin (Vincent et al., 1980). We suggest that vigorous thermohaline boundary currents inhibited sediment accumulation or even eroded older sediments on the Northwest African continental slopes while bottom currents in the adjacent basins were much weaker.

In terms of carbonate dissolution levels, the Slope was above the calcite compensation depth throughout the post-Cenomanian Cretaceous and Cenozoic.

As to the fertility of surface waters during post-Cenomanian time, as reflected in the abundance of siliceous fossils, only during Paleocene-early Eocene times was there a significant contribution, and, except for minor

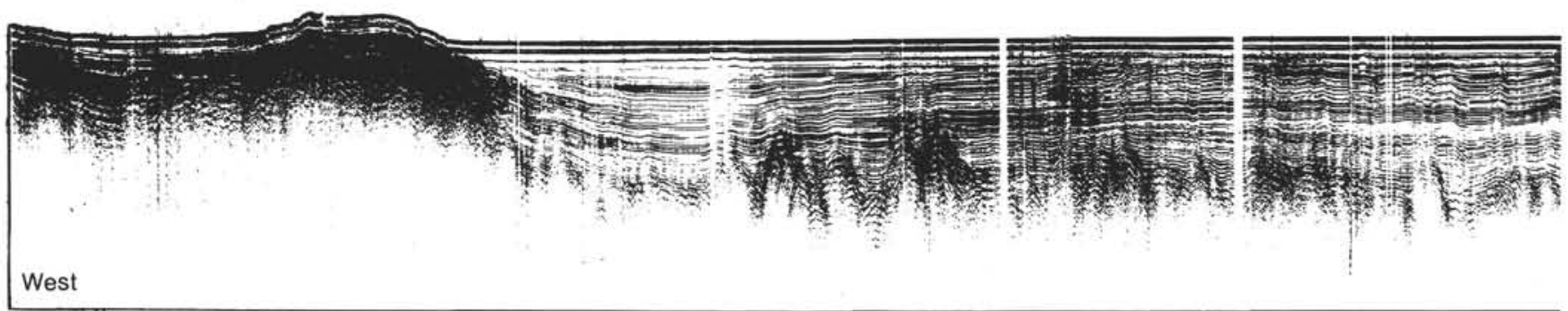

Figure 19. Multichannel seismic reflection profile extending from the older M-sequence to the Mazagan Plateau, showing the westward-thinning wedge of onlapping sediments over the Magnetic Quiet Zone seaward of the "Diapiric Front." Reproduced by courtesy of D. E. Hayes, who obtained the seismic data on Conrad cruise C 24-05 of the Lamont-Doherty Geological Observatory. The profile is taken from the quarterly newsletter Lamont, published by the Lamont-Doherty Geological Observatory, Fall, 1983, pp. 2-3. 
amounts in the early to middle Miocene of Site 545, the Neogene is remarkably poor in biogenous silica.

\section{MAJOR UNSOLVED PROBLEMS}

Although the drilling results of DSDP Leg 79 provide abundant new information regarding the Mesozoic stratigraphy, lithology, paleoenvironment, and tectonic processes that affected the evolution of the Moroccan continental margin, many major problems remain unsolved.

1. Ocean/continent boundary and accurate time at which seafloor spreading began in the central North Atlantic: There is evidence that the present-day seaward boundary of the Moroccan diapir province represents the approximate position of the ocean/continent boundary, and that actual seafloor spreading in the central North Atlantic began at about the end of the Bathonian, that is, about $25 \mathrm{~m}$.y. later than commonly assumed up to the drilling of Site 534, during Leg 76. In order to pin down this crustal boundary and to date directly the oldest oceanic crust, drilling as close as possible to the seaward boundary of the Moroccan diapir province is needed. An additional multichannel seismic site survey along the boundary of the Moroccan diapir province is required to find suitable site locations near the S-1 Magnetic Anomaly where basement can be reached in less than $3500 \mathrm{~m}$ beneath seafloor.

2. Relations among carbonate platform growth, drowning, and plate tectonic events: There appears to be a close temporal relationship between the early seafloorspreading history and the build-up, growth, and drowning of the carbonate platform. Seismic unconformity $\mathrm{B}^{*}$, which is interpreted to represent the base of the shallow-water carbonate platform, may represent the breakup unconformity if seafloor spreading began in late Bathonian time, as we suppose. The nature and age of Reflector B on the Mazagan Plateau are unknown, but we suggest that it may correspond to a change in spreading rate in the middle Late Jurassic (around M-22, 141 m.y. ago). In order to determine the date of when platform growth began, the evolutionary stages of the platform, and the subsidence history of the Mazagan Plateau, three drilling targets are suggested: (i) deepen Site 547 to basement, (ii) drill Reflectors B* and B at planning Site MAZ-8, located on the outermost Mazagan Plateau about 3 $\mathrm{km}$ southeast of Site 545, and (iii) drill the reduced Jurassic section and basement in the area of the Central Mazagan Crustal Block.

3. Progressive downfaulting and subsidence from west to east: The reflection seismic data suggest that rapid subsidence accompanied by rotational block-faulting was time-transgressive, possibly because of differences in the thickness and composition of the attenuated crust. Rapid subsidence began in those parts of the rifted basin where crustal extension was greatest. Then rapid subsidence and block-faulting progressively affected the less thinned parts of the ancient margin, possibly as a result of progressive lateral cooling (cooling front). In order to test this idea, we need to determine the depth and morphology of the crust/ mantle boundary and the thickness of the deeper crust along a transect across the margin from the ocean basin seaward of Magnetic Lineation S-1 onto the Mazagan Plateau, by means of a series of slopeparallel expanded-seismic-spread profiles (ESP) tied by two-ship-wide aperture profiles.

In addition to that, the true nature of the diapirlike structure between SP300-500 on line VA 79-02 (Figure 8 ) should be investigated by multichannel seis-

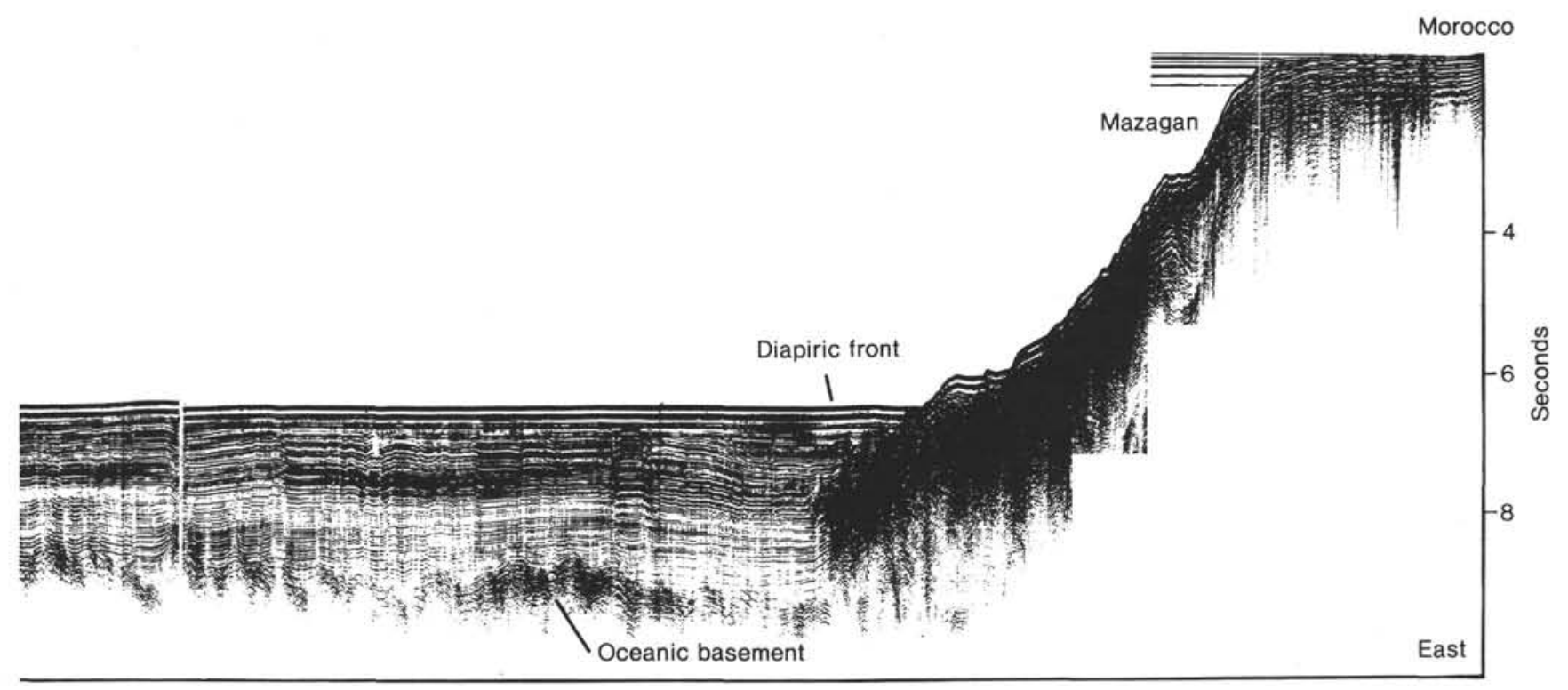

Figure 19. (Continued). 


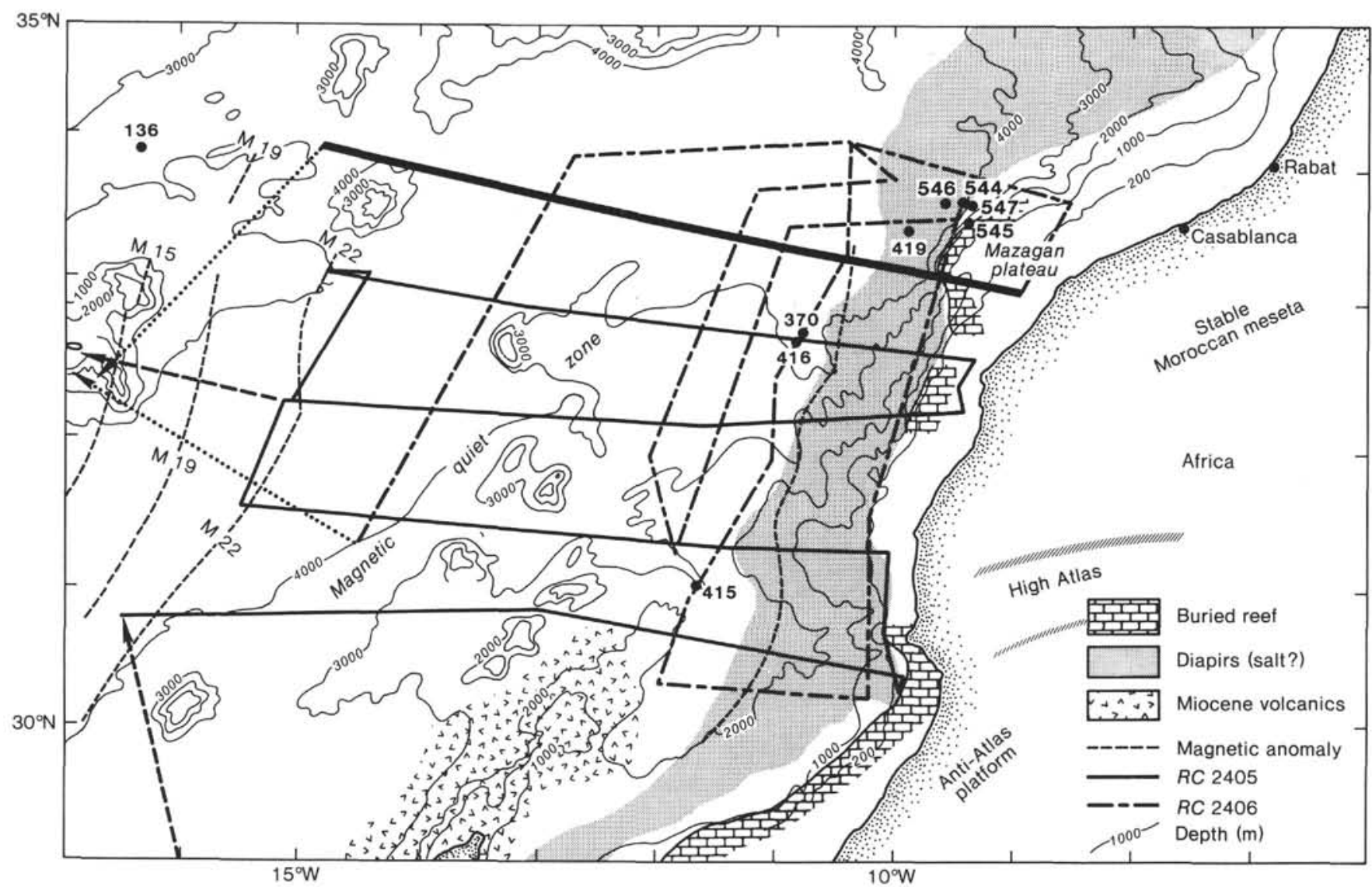

Figure 20. Index map showing location of seismic line shown in Figure 19. From D. E. Hayes, in Lamont, Fall 1983, p. 2.

mic measurements combined with detailed gravity, magnetics and, if possible, Seabeam surveys. This structure, which is tentatively interpreted as a salt diapir, is very similar in shape and seismic pattern to the sialic crustal block drilled at Site 544 .

4. Correlation of drilling results and seismic reflectors: In the area of DSDP Leg 79, the correlation between seismic reflectors and the drilling results is inadequately controlled, owing to the lack of downhole measurements. Detailed downhole measurements are needed for the proposed new sites and for reentry at Site 547.

\section{ACKNOWLEDGMENTS}

We are indebted to all our shipboard colleagues for their willingness to discuss their data and ideas with us, while we accept full responsibility for the particular interpretations presented in this chapter. We thank Dennis E. Hayes and Lamont-Doherty Geological Observatory for permission to use the seismic profile shown as Figure 19 and H. Dostmann for assistance in preparing the structural and time-contour maps. We especially acknowledge the work of Kathleen Sanderson, who prepared the final version of the cross sections, including the color frontispiece, the paleogeographic maps, and the geohistory diagrams, and of Michiko Hitchcox, who prepared the successive versions of the typescript on the word processor.

\section{REFERENCES}

Ambroggi, R., 1963. Etude Géologique du Versant Méridional du Haut Atlas Occidentale et de la Plaine de Souss. Notes Mem. Serv. Geol. Maroc, No. 157.

Beck, R. H., and Lehner, P., 1974. Oceans, new frontier in exploration. Am. Assoc. Pet. Geol. Bull., 58:376-395.
Brown, R. H., 1980. Triassic rocks of Argana Valley, Southern Moroc$\mathrm{co}$, and their regional structural implications. Am. Assoc. Pet. Geol. Bull., 64:988-1003.

Choubert, G., and Marcais, J., 1952. Géologie du Maroc: aperçu structurale. 19th Int. Geol. Congr. (Alger), Mon. Rég. Ser. 3, 6: 9-73.

Claypool, G. E., Holser, W. T., Kaplan, I. R., Sakai, H., and Zak, I., 1980. The age curves of sulfur and oxygen isotopes in marine sulfate and their mutual interpretation. Chem. Geol. 28:199-260.

Faure-Muret, A., and Choubert, G., 1971. Le Maroc. Domaine rifaine et atlasique. Tectonique de l'A frique: Paris (UNESCO), pp. 17-46.

Gradstein, F. M., and Sheridan, R. E., 1983. on the Jurassic Atlantic Ocean and a Synthesis of results of Deep Sea Drilling Project Leg 76. In Sheridan, R. E., Gradstein, F. M., et al., Init. Repts. DSDP, 76: Washington (U.S. Govt. Printing Office), 913-943.

Hayes, D. E., and Rabinowitz, P. D., 1975. Mesozoic magnetic lineations and the magnetic quiet zone off Northwest Africa. Earth Planet. Sci. Lett., 28:105-115.

Hinz, K., Dostmann, H., and Fritsch, J., 1982. The continental margin of Morocco: seismic sequences, structural elements and geological development. In von Rad, U., Hinz, K., Sarnthein, M., and Seibold, E. (Eds.), Geology of the Northwest African Continental Margin: Berlin, Heidelberg, New York (Springer-Verlag), pp. 34-60.

Hinz, K., and Seibold, E., 1980. Passive continental margins: NW Africa, North Atlantic, NW Australia. In Mobile Earth Internat. Geodynamics Project: Final Report of the Fed. Rep. Germany: Boppard (Harald Boldt Verlag), pp. 127-138.

Hinz, K., Winterer, E. L., Baumgartner, P. O., Bradshaw, M. J., Channell, J. E. T., Jaffrezo, M., Jansa, L. F., Leckie, R. M., Moore, J. N., Rullkötter, J., Schaftenaar, C., Steiger, T. H., Vuchev, V., and Wiegand, G. F., 1982. Preliminary results from DSDP Leg 79 seaward of the Mazagan Plateau off Central Morocco. In von Rad, U., Hinz, K., Sarnthein, M., and Seibold, E. (Eds.), Geology of the Northwest African Continental Margin: Berlin, Heidelberg, New York (Springer-Verlag), pp. 23-33. 
Jacobi, R. D., Rabinowitz, P. D., and Embley, R. W., 1975. Sediment waves on the Moroccan continental rise. Mar. Geol. 19:61-67.

Jansa, L. F., Bujak, J. P., and Williams, G. L., 1980. Upper Triassic salt deposits of the western North Atlantic. Can. J. Earth Sci., 17: 547-559.

Jansa, L. F., and Wade, J. A., 1975. Geology of the continental margin off Nova Scotia and Newfoundland. In van der Linden, W. J. M., and Wade, J. A. (Eds.), Offshore Geology of Eastern Canada: Regional Geology (Pt. 2). Can Geol. Surv. Pap., 74-30:51-106.

Jansa, L. F., and Wiedmann, J., 1982. Mesozoic-Cenozoic development of the eastern North American and Northwest African continental margins: a comparison. In von Rad, U., Hinz, K., Sarnthein, M. and Seibold, E. (Eds.), Geology of the Northwest African Continental Margin: Berlin, Heidelberg, New York (SpringerVerlag), pp. 215-269.

Lancelot, Y., Seibold, E., et al., 1978. Init. Repts. DSDP, 41: Washington (U.S. Govt. Printing Office).

Lancelot, Y., and Winterer, E. L., 1980. Evolution of the Moroccan oceanic basin and adjacent continental margin-a synthesis. In Lancelot, Y., Winterer, E. L., et al., Init. Repts. DSDP, 50: Washington (U.S. Govt. Printing Office), 801-821.

Le Pichon, X., Sibuet, J. -C., and Francheteau, J., 1977. The fit of the continents around the North Atlantic Ocean. Tectonophysics, 38:169-209.

Luyendyk, B. P., and Bunce, E. T., 1973. Geophysical study of the Northwest African margin of Morocco. Deep-Sea Res., 20:537-549.

McMaster, R. L., and La Chance, T. P., 1968. Seismic reflection studies on northwestern African continental shelf. Strait of Gibralter to Mauritania. Am. Assoc. Pet. Geol. Bull., 52:2387-2396.

Ogg, J. G., and Steiner, M. B., in press. Jurassic magnetic polarity pattern: time scale and reversal frequency. Abst. with Progr., Session C20, 27th Int. Geol. Cong., Moscow.

Price, I., 1980. Gravity tectonics on a passive margin: Deep Sea Drilling Project Site 415 in relation to regional seismic data. In Lancelot, Y., Winterer, E. L., et al., Init. Repts. DSDP, 50: Washington (U.S. Govt. Printing Office), 759-771.

Renz, O., Imlay, R., Lancelot, Y., and Ryan, W. B. F., 1975. Ammonite-rich Oxfordian limestones from the base of the continental slope off Northwest Africa. Eclogae Geol. Helv., 68:431-448.

Robb, J. M., 1971. Structure of the continental margin between Cape Rhir and Cape Sim, Morocco, Northwest Africa. Am. Assoc. Pet. Geol. Bull., 55:643-650.

Roeser, H., 1982. Magnetic anomalies in the Magnetic Quiet Zone off Morocco. In von Rad, U., Hinz, K., Sarnthein, M. and Seigold, E. (Eds.), Geology of the Northwest African Continental Margin: Berlin, Heidelberg, New York (Springer-Verlag), pp. 60-68.

Salvan, H. M., 1974. Les séries salifères du Trias marocain; caractères généraux et possibilités d'interprétation. Bull. Soc. Geol. France, 7:724-731.

Salvatorini, G., and Cita, M. B., 1979. Miocene foraminiferal stratigraphy, DSDP Site 397 (Cape Bojador, North Atlantic). In von Rad, U., Ryan, W. B. F., et al., Init. Repts. DSDP, 47, Pt. 1: Washington (U.S. Govt. Printing Office).

Seibold, E., and Hinz, K., 1974. Continental slope construction and destruction, West-Africa. In Burk, C. A. and Drake, C. L. (Eds.), New York, Heidelberg, Berlin (Springer Verlag), pp. 179-196. 1976. German cruises to the continental margin of Northwest Africa in 1975: General reports and preliminary results from "VALDIVIA" 10 and "METEOR" 39. "Meteor" Forsch. Reihe C, 25:47-80.
Sheridan, R. E., 1983. Phenomena of pulsation tectonics related to the breakup of the Eastern North American Continental Margin. In Sheridan, R. E., Gradstein, F. M., et al., Init. Repts. DSDP, 76: Washington (U.S. Govt. Printing Office), 897-909.

Sheridan, R. E., Gradstein, F. M., and Shipboard Scientific Party, 1983. Site 534. In Sheridan, R. E., Gradstein, F. M., et al., Init. Repts. DSDP, 76: Washington (U.S. Govt. Printing Office), 141-340.

Summerhayes, C. P., Nutter, A. H., and Tooms, J. S., 1971. Geological structure and development of the continental margin of Northwest Africa. Mar. Geol., 11:1-25.

Tooms, J. S., Summerhayes, C. P., and McMaster, R. L., 1971. Marine geological studies on the northwest African margin: Rabat-Dakar, ICSU/SCOR Working Group 31 Symposium 4, Africa, (Cambridge, 1970). Inst. Geol. Sci. Report. No. 70/16:13-25.

Uchupi, E., and Emery, K. O., 1974. Seismic Reflection, Magnetic, and Gravity Profiles of the Eastern Atlantic Continental Margin and Adjacent Deep Sea Floor: II Congo Canyon (Rep. of Zaire) to Lisbon (Portugal). Woods Hole Oceanogr. Inst. Ref. No. 74-19.

Uchupi, E., Emery, K. O., Bowin, C. O., and Phillip, J. D., 1976. The continental margin off Western Africa: Senegal to Portugal. Am. Assoc. Pet. Geol. Bull., 60:809-878.

Vail, P. R., Mitchum, R. M., Shipley, T. H., and Buffler, R. T., 1980. Unconformities of the North Atlantic. In Kent, P., et al. (Eds.), The Evolution of Passive Continental Margins in the Light of Recent Deep Drilling Results: London (Royal Society), pp. 137-155.

Vail, P. R., Mitchum, R. M., Todd, R. G., Widmier, J. M., Thompson, S., Sangree, J. B., Bubb, J. N., and Hatlelid, W. G., 1977. Seismic stratigraphy and global changes of sea level. Seismic stratigraphyapplication to hydrocarbon exploration. Am. Assoc. Pet. Geol. Mem., 26:49-212.

van Hinte, J. E., 1976. A Jurassic time scale. Am. Assoc. Pet. Geol. Bull., 60:489-497.

Van Houten, F. B., 1977. Triassic-Liassic deposits of Morocco and Eastern North America: comparison. Am. Assoc. Pet. Geol. Bull., 61:79-99.

Vincent, E., C̈epek, P., Sliter, W. V., Westberg, M. J., and Gartner, S., 1980. Biostratigraphy and depositional history of the Moroccan Basin, Eastern North Atlantic. In Lancelot, Y., Winterer, E. L., et al., Init. Repts. DSDP, 50: Washington (U.S. Govt. Printing Office), 775-800.

Vogt, P. R., 1973. Early events in the opening of the North Atlantic. In Tarling, D. H., and Runcorn, S. K. (Eds.), Implications of Continental Drift to the Earth Sciences (Vol. 2): London (Academic Press), 693-712.

Vogt, P. R., and Einwich, A. M., 1979. Magnetic anomalies and seafloor spreading in the Western North Atlantic and a revised calibration of the Keathley (M) geomagnetic reversal chronology. In Tucholke, B. E., Vogt, P. R., et al., Init. Repts. DSDP, 43: Washington (U.S. Govt. Printing Office), 857-876.

Weigel, W., Wissmann, G., and Goldflam, P., 1982. Deep seismic structure (Mauretania and Central Morocco). In von Rad, U., Hinz, K., Sarnthein, M., and Seibold, E. (Eds.), Geology of the Northwest African Continental Margin: Berlin, Heidelberg, New York (SpringerVerlag), pp. 132-159.

Wissmann, G., and von Rad, U., 1979. Seismic structure, continental basement, and Mesozoic sediments from the Mazagan Plateau off Morocco. "Meteor" Forsch. Reihe C., 31:1-20.

Date of Acceptance: May 4, 1984 